\title{
GOVERNMENTS AS PARTNERS: THE ROLE OF ALLIANCES IN U.S. CLEANTECH STARTUP INNOVATION
}

\author{
Claudia Doblinger ${ }^{1}$, Kavita Surana ${ }^{2}$, Laura Diaz Anadon ${ }^{3,4}$
}

\author{
${ }^{1}$ School of Management, Technical University of Munich (TU Munich) \\ ${ }^{2}$ School of Public Policy, University of Maryland \\ ${ }^{3}$ Center for Environment, Energy and Natural Resource Governance, Department of Land \\ Economy, University of Cambridge \\ ${ }^{4}$ Belfer Center for Science \& International Affairs, Harvard Kennedy School
}

\begin{abstract}
Accelerating innovation in clean energy technologies is a policy priority for governments around the world aiming to mitigate climate change and to provide affordable energy. Most research has focused on the role of governments financing R\&D and steering market demand, but there is a more limited understanding of the role of direct government interactions with startups across all sectors. We propose and evaluate the value-creation mechanisms of network resources from different types of partners for startups, highlighting the unique resources of government partners for cleantech startups. We develop and analyze a novel dataset of 657 U.S. cleantech startups and 2,015 alliances with governments, firms, research organizations, and not-for-profit organizations from 2008 to 2012 and analyze short-term firm outcomes from the different alliances. Our findings highlight the importance of governmental partners in technology development alliances to catalyze cleantech startup innovation (the patenting activity of cleantech startups increases by 73.7 percent with every additional governmental technology alliance when compared to those startups that did not engage in such alliances) and as quality signals to private sector investors for licensing alliances (private financing deals increase by 155 percent for every additional license from a government organization). Overall, these findings extend the alliance perspectives on innovation,
\end{abstract}


contribute to the emerging research on entrepreneurial ecosystems, and underline the need to develop empirical evidence in different sectors.

Keywords: Cleantech, Innovation, Public Policy, Entrepreneurship, Ecosystems 


\section{Introduction}

Accelerating technological innovation in the energy sector-and particularly in the clean power and transportation, or cleantech sector-has become a public policy priority in countries around the world, as reflected in the 2015 Paris Agreement (UNFCCC, 2015b) and the recent IPCC Global Warming of $1.5^{\circ} \mathrm{C}$ report (IPCC, 2018). This is because mitigating global climate change, reducing local air pollution from fossil powered electricity and transportation, and providing reliable and affordable energy for all represent some of the most difficult challenges of the 21 st century (United Nations, 2015). Prior research on how governments can promote technological innovation has identified two primary classes of governmental roles: the provision of public funding or incentives to lower the cost of research and development (R\&D) in universities, research laboratories, or firms (or 'technology push'), and the implementation of policies to increase the rewards to innovators by creating or shaping markets (or 'demand pull', which in the case of the cleantech sector includes feed-in-tariffs, tax credits, or carbon prices) (e.g., Bettencourt et al., 2013; Howell, 2017; Mowery and Rosenberg, 1979; Nemet, 2009; 2018; Schmidt and Sewerin, 2018). But more recently, researchers and governments alike have challenged the traditional role of government in supporting innovation. The rapid growth of startups, i.e., recently founded firms in their first years of existence, and the venture capital (VC) funding community since the 2000s in the United States (U.S.) initially in the information technology (IT) and biotech sectors, and later in cleantech (Gaddy et al., 2017) has raised questions on the extent to which governments are needed to create supportive conditions for technology startups to realize their potential (Guzman and Stern, 2015; Samila and Sorenson, 2010). In parallel, new national energy innovation policies have been created to promote different types of interactions, or alliances, between the public and private actors in the U.S. and elsewhere (Anadon, 2012; Chan et al., 2017). Many of these new institutions to advance technology innovation in the cleantech space have increasingly focused on providing 
incubator services to support startups (e.g., DOE, 2018b). There has also been significant action to better connect public and private R\&D and startup funding activities at an international level. ${ }^{1}$

However, to date there is little empirical research on the value of direct alliances between government organizations and cleantech startups to shape technological innovation in the energy space.

Governments and startups have a contrasting, yet highly complementary, set of resources and priorities to foster $R \& D$ in the cleantech sector. Government organizations make up a significant fraction of total R\&D efforts in most countries (Mazzucato, 2013). In the U.S. for example, publicly-funded agencies funded about 27\% of all R\&D in 2013 (NSF, 2016). There are several government organizations, which are defined as public agencies that have the mission to advance technological innovation and to contribute to technology transfer in the energy space either through funding, conducting, or supporting R\&D (Anadon, 2012; Goldstein and Narayanamurti, 2018). ${ }^{2}$ It has been argued that these publicly-funded organizations have the resources, the ability (e.g., critical mass), and the mandate to invest in or carry out efforts that could have payoffs in the longer term when compared to the efforts of private firms (Anadon et al., 2016; Westwick, 2003). For example, on average, each laboratory of the Department of Energy (DOE) involved in energy technology had an annual budget of 317 million USD for energy R\&D in 2014, and they possess

\footnotetext{
1 For example, two high-level initiatives materialized with the Paris Agreement: Mission Innovation and the Breakthrough Energy Coalition (the first one led by national governments, the second by private actors, but with the idea of acting in concert). The Mission Innovation initiative comprises governments of 20 major global economies that pledged to accelerate public and private global clean technology innovation and to double their public R\&D investments by 2020. The private sector's Breakthrough Energy Coalition, initially comprising 27 private investors, committed to investing early in technologies that can help mitigate climate change and bring in long-term 'patient' capital investments to help accelerate the commercialization of the outputs from the Mission Innovation funding increase (UNFCCC, 2015a).

2 In the U.S., these government organizations include (at the federal level) the Department of Energy (DOE), its seventeen national laboratories (sixteen federally funded R\&D centers-FFRDCs - and one government owned and government operated center), and some of its new funding programs (including ARPA-E); other federal agencies, such as the National Aeronautics and Space Administration (NASA) and the Department of Defense; and state level agencies, such as the New York State Research and Development Agency (NYSERDA) (USA.gov, 2018). This definition of government organizations as publicly funded agencies with the mission to promote (energy) innovation does not include public and private universities as well as private research institutes.
} 
unique demonstration and testing facilities (Bin-Nun et al., 2017). These organizations may possess important resources for cleantech innovation as a result of the multi-decade technology development cycles for energy supply technologies, the high capital intensity in the energy sector and path dependencies with existing fossil fuel-based infrastructures. Furthermore, unlike in the space or defense domains, where government organizations also play a pivotal role as the main customer (or market), the energy sector is largely in the hands of the private sector. This implies that the defense and space models of bridging technology-push and market-pull (largely through the role of the government as customer) are not directly applicable to the energy sector, where different types of instruments for addressing climate change and accelerating energy innovation are needed (Mowery et al., 2010).

Compared to government organizations engaged in R\&D and commercialization, startups are perceived to be agile and flexible with the ability to respond to market opportunities in the nearterm by commercializing novel solutions. These characteristics make startups particularly apt for the urgent solutions needed in the cleantech sector (e.g., Audretsch et al., 2006; Howell, 2017). However, startups experience resource constraints and operate under a short-term imperative for achieving successful outcomes (over 1-2 years) (Baum, 1996; Baum et al., 2000). The quickness and agility that startups can leverage in sectors with short development cycles (e.g., IT) (Bettis and Hitt, 1995) may be more challenging for cleantech startups due to the sector's longer term technology development requirements and resource intensity as outlined above.

Forming alliances to access critical and complementary resources is an important strategy for startups to overcome resource constraints and to achieve superior outcomes (Pfeffer and Salancik, 1978). This importance of alliances as described by resource dependence theory (RDT) is supported by several streams of research including interorganizational alliances and knowledge, innovation, or entrepreneurial (eco-)systems, which often build on empirical research in the biotech, 
manufacturing, or IT sectors. The typical suggestion is that firms should collaborate as much with as many diverse partners as possible to benefit from diverse knowledge channels and important network resources such as partners' R\&D capabilities or reputation (e.g., Adner and Kapoor, 2010; Autio et al., 2014; Clarysse et al., 2014; Iansiti and Levien, 2004; Lavie, 2006, 2007; Musiolik et al., 2012; Musiolik et al., 2018; Nemet, 2012; Nemet and Johnson, 2012; Powell et al., 1996).

However, for startups to bring in and engage with diverse partners - when the partners have varying institutional norms, habits, and rules - may be challenging and sometimes infeasible given that startups face greater resource constraints than larger firms and that partnering is by itself a resource-intense endeavor (Laursen and Salter, 2006). The process of forming an alliance further produces "new patterns of dependence" (Hillman et al., 2009: 1405). Even though partnering with organizations that have the most critical and complementary resources might be important for achieving superior outcomes, private partners are typically powerful and often tend to benefit more from the relational and spillover rents than the focal firm (Katila et al., 2008; Lavie, 2006). Overall, resource-constrained startups need to be selective in their partner choice and determine (a) which partner possesses critical resources and (b) how they can appropriate value from the alliance.

Extant research has overlooked three elements in this context. First, research has primarily focused on the role of larger firms, universities, or newer forms of intermediary organizations (such as accelerators) in shaping entrepreneurial ecosystems (e.g., Autio et al., 2014; Clarysse et al., 2014; Clayton et al., 2018; Iansiti and Levien, 2004), and often neglected the role of governments in directly promoting startup innovation through (1:1) alliances. Second, research has often overlooked the mechanisms of how startups can create value from network resources in different types of alliances - for example, startups may benefit differently from resource synergies and tacit knowledge exchanges in technology development alliances when compared to getting direct access to codified knowledge in the form of licensing alliances (Conti et al., 2013; Deeds and Hill, 1996; 
Hsu and Ziedonis, 2013; Islam et al., 2018; Lavie, 2007). And third, literature on startups and alliances has relied on evidence mainly from the biotech and IT sectors, but recent research suggests there may be value in adding empirical evidence from the cleantech sector (Gaddy et al., 2017). In cleantech, the role of the U.S. government organizations in particular and of other governments around the world is central to understanding the technologies we enjoy today. Determining the value of different exchanges for cleantech innovation thus requires extending research to include governments and other partners in distinct types of alliances while simultaneously focusing on "the importance of breadth and depth of external search to innovative performance within each channel or knowledge domain” (Laursen and Salter, 2006: 133).

This paper addresses these knowledge gaps by answering the following questions: (a) What role do alliances with governments play in enabling cleantech startup innovation activity and in increasing the ability to attract financial investments when compared to other partners? (b) What are the mechanisms in technology development and licensing alliances through which startups create value and generate positive outcomes for startups? To address these questions, we develop a novel dataset of the global alliances of 657 U.S. cleantech startups that had been in existence for a maximum of five years from 2008 to 2012 , and classify startup partners as government organizations, research institutes and universities, not-for-profit organizations, and other firms (startups and established firms). We focus on the value-creation mechanisms in licensing and technology development alliances as opposed to market-based alliances such as procurement because of the emphasis on technological advancements in the energy space and the fact thatunlike in the defense industry — governments are not the primary customers (Mowery et al., 2010). ${ }^{3}$ We posit that governmental partners hold discretion over particularly useful technological and

\footnotetext{
3 Market-based alliances such as procurement are included as controls and discussed in Section 5.
} 
physical resources for cleantech startup innovation (Anadon, 2012; Bonvillian, 2014; Koonin and Gopstein, 2011). We argue that the network resources from technology development alliances with government partners are more valuable to cleantech startups in terms of short-term innovation outcomes (patenting activity) than those available from universities and private research institutes, or other firms. We further show that licensing alliances with government organizations enable access to important social resources that could enhance the legitimacy of startups and help in attracting financial investments (Islam et al., 2018). Overall, we provide novel evidence that the negative impact of power imbalance - where the stronger party appropriates more value than the smaller one, often prevalent in alliances between startups and other firms or other profit-oriented partners (Cox Pahnke et al., 2015; Gulati et al., 2011) — does not seem to apply to the case of cleantech startup alliances with government organizations because of the latter's distinct mandate to promote (energy) innovation and technology transfer.

The remainder of the paper is structured as follows. In Section 2 we review the literature and lay out our hypotheses. In Section 3 we present the dataset we develop and describe the methods used to analyze it, including various robustness checks. In Section 4 we present the key results and follow with a discussion of the implications for the academic literature in Section 5 and for public policy in Section 6. We conclude with limitations and directions for future research in Section 7.

\section{Theory and Hypotheses}

We review in turn the literature on alliances and the importance of network resources for startups. We then summarize the review to present our hypotheses. 


\subsection{Network resources for startup innovation and financial investments}

According to RDT, the formation of interorganizational alliances and the underlying access to critical resources serves as an important means for firms to reduce the uncertainty of their environment and to overcome the constraints imposed because of limited internal resources (Casciaro and Piskorski, 2005; Pfeffer and Salancik, 1978). Several separate streams of literature support this importance of developing co-evolving and mutually rewarding alliances and the need to secure access to critical network resources using macro- or systems-level and firm-level analyses.

In macro-level analyses of (technological) innovation systems, interorganizational alliances represent one of many possible interactions among institutions and actors including governments, firms, and entrepreneurs (e.g., Bergek et al., 2008; Hekkert et al., 2007). Technological innovation systems (TIS) analysis highlights that, in addition to the financial and human resources of the individual actors and system resources such as the emergence of standards, network resources such as reputation, trust, and creation of shared goals from alliances are important for technology development (Musiolik et al., 2012; Musiolik et al., 2018). Moreover, research has highlighted the importance of knowledge spillovers from acquiring technological knowledge from diverse channels by analyzing patent citations, where citations external to the technological domain may have a stronger influence on innovation success (Nemet, 2012; Nemet and Johnson, 2012).

In firm-level analyses, the literatures on interorganizational alliances and (knowledge, innovation, business, or entrepreneurial) ecosystems highlight that innovation is typically a result of alliances between different types of actors. These studies often rely on case study analysis, or local cluster analysis methods and have typically studied established firms and, occasionally, startups, universities, or research institutes (e.g., Adner, 2006; Adner and Kapoor, 2010; e.g., Autio et al., 2014; Baum et al., 2000; Clarysse et al., 2014; Dyer and Singh, 1998; Iansiti and Levien, 2004; 
Laursen and Salter, 2006; Powell et al., 1996; Von Hippel, 1978). Overall, research on alliances indicates that diversity of partner types is not only a typical characteristic of effective ecosystem development (Clayton et al., 2018), but also increases firm innovation and the likelihood of succeeding in the market (Demirkan and Demirkan, 2012; Laursen and Salter, 2006).

However, the recommendation to collaborate as much with as many diverse partners as possible to benefit from network resources may not be feasible for startups in general and for cleantech startups in particular. As partners may have different institutional norms and practices, engaging productively with different types of partners requires time-intensive and costly organizational practices and coordination mechanisms (Laursen and Salter, 2014). For example, alliances with suppliers and customers typically require careful consideration of disclosure of knowledge on products and technologies and extensive mutual coordination and commitment (Dyer and Singh, 1998; von Hippel, 1988). In contrast, collaborating with a government organization, such as a U.S. national laboratory or a state-level energy agency, involves a different type of process that may require higher levels of bureaucracy, distinct cultural attitudes, contractual rules, and costs (Glauthier and Cohon, 2015). Bringing in a strong diversity in partners may therefore be particularly challenging for startups that are generally subject to greater resource constraints in terms of personnel or cash flow when compared to larger firms.

Hence, resource-constrained startups need to be selective in their partner choice. In other words: "The organization can seldom dictate which resources its partners will own, but it can decide, to some extent, who to partner with" (Gulati et al., 2011: 215). To benefit from alliances, startups thus need to forge relations with those partners that have the greatest discretion over critical resources that complement the startup's resource portfolio. Alongside physical products, these potentially valuable resources for startups include technological knowledge and social status or prestige (Hillman et al., 2009; Lavie and Drori, 2012; Pfeffer and Salancik, 1978). These resources 
are specific to the structure and the actors of the sector in which the startup is active. As we discuss below, the literature shows that the energy sector, i.e., the context for cleantech startups, is significantly different from other sectors that have been the focus of most research on startup alliances to date.

The structure of the cleantech sector is defined by three interrelated characteristics: (a) electricity and fuels are commodities that are often regulated, as electricity and transportation services are key to human well-being and the functioning of a state; (b) the rate of transformation in the energy sector infrastructure is slow since it takes multiple decades to develop and deploy new products for generating and storing different forms of energy; and (c) high capital intensity and lumpiness of investments, path dependencies, and lock-ins with existing fossil fuel-based infrastructures mean that changes in infrastructure and institutions are needed to make new energy sources available (Fouquet, 2013; Grubler et al., 2012; Koonin and Gopstein, 2011; Nanda et al., 2015; Unruh, 2000). The valuable network resources required for cleantech startups may therefore be held by organizations that have a longer term perspective for their research activities, substantial and energy specific research experience, physical equipment and dedicated researchers, as well as the willingness to contribute to technology transfer to the private sector. In the cleantech sector, we can distinguish between three groups of actors: government organizations, private actors, and universities. Government organizations include government departments, such as the DOE, or the national laboratories, such as the National Renewable Energy Laboratory (NREL), owned by DOE and with particular missions including the long-term promotion of (energy) innovation and technology transfer in the case of the U.S. (e.g., Bin-Nun et al., 2017; Westwick, 2003). Public and private universities as well as private research institutes, such as MIT or the Western Research Institute, typically have a mandate for research, training, and education (e.g., American Academy of Arts and Sciences, 2013; Boccanfuso, 2010; Henderson et al., 1998). Private sector firms active in 
the cleantech sector generally have the mandate to provide returns to stakeholders (e.g., Drucker, 1958). In Table 1, we summarize the network resources from these three different actor groups that are potential alliance partners for cleantech startups.

Insert Table 1 about here

We link the different types of resources owned by the three actors (Table 1) to alliance types that enable positive outcomes for startups (i.e., increased innovation and financing) based on the three value-creation mechanisms proposed by Lavie (2007): (1) directly accessing technological resources in the form of codified knowledge through licenses that complement startup's internal resources and might directly increase startup outcomes; (2) directly accessing physical and technological resources and transferring tacit knowledge in technology development alliances, which enables resource combinations and synergies between network and internal resources that together contribute to superior outcomes; and (3) facilitating indirect returns through knowledge spillovers that enable the internalization of external technological resources (in addition to the relational ones), or through legitimacy increases as a result of providing social resources such as trust and credibility (Lavie, 2007). We argue that knowledge spillovers and legitimacy increases might be prevalent in both licensing and technology development alliances. Overall, we posit that cleantech startups benefit especially from forming licensing and technology development alliances with government organizations as a result of greater resource complementarity and reduced power imbalance when compared to other partners. Figure 1 summarizes our theoretical model, which we further explain in the following. 


\subsection{Importance of network resources from governmental partners for innovation}

Startups can create value from their alliances by directly acquiring codified knowledge from their partner(s) (Lavie, 2007). Licensing alliances with partners that possess critical resources enable direct access to technological knowledge in return for a fee or royalty. Prior research from the biotech sector has argued that the technological network resources transferred in licensing alliances with universities or research institutes are important for startup innovation, though to a lesser extent than technology development alliances (Baum, 1996; Baum et al., 2000; Liebeskind et al., 1996). In the cleantech space, government organizations manage and receive funding for conducting research over longer periods - sometimes even decades — when compared to universities or private research institutes and especially to private sector firms, thus possessing unique technological expertise in cleantech as well as in related technologies (Anadon, 2012; Bonvillian, 2014). They have the specific mandate to promote discovery science, energy security and independence, national security, and economic prosperity and global competitiveness (DOE, 2017). In addition, these organizations often have a critical mass of researchers, i.e., a greater amount of dedicated personnel for (energy) innovation, with lower staff fluctuation when compared to universities and private research institutes, or private firms. Given that the development and deployment of new energy products often takes multiple decades and requires high capital intensity, government organizations have potentially built unique technological capabilities and a wide human and technological resource base spanning the energy space (Cohen and Noll, 1996; Koonin and Gopstein, 2011; Westwick, 2003). These network resources from government organizations thus bring in technological expertise on cleantech that may serve as key complements to the short-term outlook, agility, and market feedback of startups. 
We suggest that network resources in the form of codified knowledge in licenses from government organizations are characterized by greater resource complementarity and may lead to more technological benefits that result in additional innovation activities than the ones from universities and private research institutes, or private sector firms. Private sector firms are profitdriven and typically reluctant to share additional knowledge that bears the risk of reducing their own competitive advantage. While universities widely disseminate their knowledge and contribute to private sector innovation through spillovers (e.g., Henderson et al., 1998; Jaffe, 1989), publications rather than direct interactions with startups to transfer additional knowledge remain a priority. But rationales of knowledge spillovers also apply to government organizations - for example, Chan (2015) found that government laboratories' licenses to private firms resulted in increased follow-on patenting activity of the licensee firms and in follow-on patenting at other firms. We argue that the spillovers from government organizations in the cleantech space may be larger (than with other partners) because they result from the internalization of additional technological knowledge that emerges from the more frequent and direct interaction with government personnel who facilitate the licensing process. Furthermore, licenses from government organizations may be acquired in areas beyond a firm's own set of competencies (e.g., Arora, 1995), which could be associated with a greater potential to learn and to generate subsequent innovation, at least on a longer term horizon.

Thus, our first hypothesis is that for startups, government organizations are key partners (compared to universities and private research institutes as well as to private firms) that allow access to codified knowledge and to personal interactions, thus enabling startups to fully capture the value of licenses. Given startups' resource constraints and the short-term imperative to achieve successful outcomes, licensing alliances with government organizations represent the lowest risk and, potentially, most valuable option for startups to generate value from technological resources. 
Hypothesis 1: For startups in the cleantech sector, licensing alliances with government organizations are more positively associated with increases in patenting activity by the startup when compared to other alliance partners.

Technology development alliances, such as when startups engage in joint R\&D, demonstration, or testing activities with other partners, enable the sharing and exchange of tacit technological knowledge, the spreading of risk, and resource synergies between network and internal resources (Lavie, 2007). Prior research has shown how firms that forge technology development alliances with other firms, research institutes, or universities experience increased levels of innovation in terms of patenting activity or new product development (Clarysse et al., 2014; Deeds and Hill, 1996). As indicated above, government organizations manage and receive funding for conducting energy research over longer periods when compared to other partners for cleantech startups. Various studies suggest that a range of energy technologies such as solar, energy efficiency, or fracking are hard to explain without the funding and collaboration activities of governments (Anadon et al., 2014; DOE, 2018a; Nordhaus et al., 2012; NRC, 2001). These activities supplemented and shaped those of private firms in a range of areas, including IT, defense, health, and energy (Mazzucato, 2013). In addition to these complementary technological resources, government organizations possess unique physical resources such as comprehensive demonstration and testing facilities for new technologies (Koonin and Gopstein, 2011) that are important for enabling experimentation. For example, the DOE national laboratories are stewards of around 30 unique scientific instrumentation and research facilities, which require "major investments beyond the means of individual universities and firms" (DOE, 2017: 2). Technology development alliances with government organizations may thus enable access to complementary technological and physical resources that may not be available to cleantech startups otherwise. 
While access to complementary resources is important for overall knowledge generation and relational returns that cannot be generated by a single party in the alliance (Dyer and Singh, 1998; Wright et al., 2004), the value appropriation mechanisms, i.e., the relative share of the relational returns, might differ significantly between partner types (Lavie, 2007). There is often an imbalance whereby high-margin partners that possess critical resources are typically more powerful and tend to benefit more from both the relational and spillover rents than the focal firm, especially in the case of startups (Katila et al., 2008; Lavie, 2006). In this context, the concept of power imbalance describes the power difference or ratio of power of the more to the less powerful actor (Lawler and Yoon, 1996). Thus, one may argue that power imbalance and the inherent costs of partnering with resource-rich firms may outweigh the benefits of alliances (Bae and Gargiulo, 2004; Casciaro and Piskorski, 2005), which can lead to declining performance of the smaller party (Lavie, 2007). In addition, conflict over knowledge and concerns about appropriability is widely considered a barrier to alliances with larger, powerful partners. For example, strict regulations from the legal departments, complex negotiations, compounded with mechanisms to ensure secrecy may restrict emergent alliances (Laursen and Salter, 2014). In the case of universities or private research institutes, the incentive to publish the results of the technology development alliance either in the form of a research paper or in a press announcement for publicity (American Academy of Arts and Sciences, 2013) can conflict with non-disclosure developments or the securing of jointly-developed knowledge in the form of patents. In contrast, government organizations are explicitly mandated to contribute to knowledge and technology transfer to private firms (DOE, 2014). ${ }^{4}$

Thus, our second hypothesis is that for startups, government organizations are important partners (compared to universities and private research institutes as well as to private firms) that

\footnotetext{
${ }^{4}$ For example, in the U.S., the Bayh-Dole Act of 1980 was put in place to promote private sector development and commercialization of government funded $R \& D$ by facilitating licenses of patents obtained with government-funded research by private firms (Schacht, 2009).
} 
provide access to unique physical resources such as testing facilities, to technological resources such as knowledge and expertise on related technological areas or on pursuing demonstration activities for new technological developments. This greater resource complementarity combined with the reduced power imbalance of government partners when compared to private sector firms suggests that technology development alliances with government organizations potentially represent the most valuable option for startups to generate value from technological and physical resources through joint technology development. Thus:

Hypothesis 2: For startups in the cleantech sector, technology development alliances with government organizations are more positively associated with innovation activity by the startup when compared to other alliance partners.

\subsection{Importance of network resources from governmental partners for financial investments}

In addition to providing access to valuable technological and physical resources, alliances with government organizations may also provide access to critical social resources, such as increased credibility or status. These network resources are important for startups to increase their legitimacy in the eyes of external stakeholders and overcome their liabilities of newness (Hillman et al., 2009; Pfeffer and Salancik, 1978). In particular, investors face high levels of uncertainty in evaluating startups, especially in emerging industries such as cleantech, where prospective investors have less experience and the remedies of their investments have been less effective than in other sectors such as biotech (Gaddy et al., 2017). Research has found that codified knowledge in the form of startup licenses from key partners can have important signaling effects for private sector investors (Conti et al., 2013; Hsu and Ziedonis, 2013).

The importance placed on a signal comes from its ability to resolve a critical uncertainty about the startup's prospects and its likelihood to realize successful market outcomes such as 
introducing required products and technologies (Islam et al., 2018). Investors thus often rely on signals such as patents or other codified forms of knowledge to assess the prospects of potential portfolio companies (Laursen and Salter, 2014). Engaging in a licensing alliance with a governmental partner who has a strong reputation to commercialize a specific technology can thus represent a feasible strategy for startups to convince potential investors about its promising prospects (Booker et al., 2012), given the perceived ability of startups to use an existing technological knowledge base and directly transfer it into new products or technologies. Furthermore, particularly important for the energy sector is the fact that such licensing alliances enable access to dedicated researchers at government organizations who can advise startups on complementary technologies or on future developments (Nemet, 2012). Therefore for investors, licensing alliances may enable more accurate assessments of the startups' technological prospects.

Whereas prior research has found that "partners that possess the most valuable resources are not necessarily the finest associates" and "may be well positioned to appropriate the lion's share of relational rents" (Lavie, 2007: 1207), just like in the previous hypothesis, we argue that even though government organizations may possess the most valuable resources for cleantech startups, the negative consequences of alliances from power imbalances are significantly reduced because of their distinct mandate and underlying incentives when compared to private sector firms, universities and research institutes as outlined above. Overall, this might increase the startup's legitimacy vis-àvis potential investors. Given these arguments, we propose testing a third hypothesis:

Hypothesis 3: For startups in the cleantech sector, licensing alliances with government organizations are more positively associated with increases in private financial investments in the startup when compared to other alliance partners. 
The excellent technical reputation of government organizations combined with their ability to provide direct access to critical technological and physical resources through technology development alliances when compared to universities and private research institutes may further provide an important quality signal to investors and capital markets. Prior research suggests that technology development alliances not only increase startup performance in terms of sales or net income to sales ratio (Hagedoorn and Schakenraad, 1994; Lechner et al., 2006), but can also provide signaling effects of connectedness to key partners (Stuart, 2000). In emerging sectors like cleantech, there is a stronger need for startups to engage in relationships that help to minimize information and experience deficits of financial investors (Rawhouser et al., 2016). Signals such as technology development alliances with partners who have a reputation for technology expertise may help boost the reputation of the startup itself to investors (Islam et al., 2018). Potential investors from the private sector, i.e., VCs or banks, may also value the longer term time frame that is inherent in technology development alliances between governmental partners and startups when compared to other partner types. The political mandate of governments of focusing on energy innovation and on more radical, and therefore also more risky, technology developments (Leyden and Link, 2015; Mazzucato, 2013) could further be important to potential investors.

Investors potentially value that the tacit knowledge exchanged in technology development alliances with government organizations, when compared to private firms, lower the risk of information leakages and knowledge outflows to competitors. Knowledge outflows represent a serious threat to startups that typically depend on single technologies and products. Even though these threats can be reduced through non-disclosure agreements and other formal mechanisms to ensure intellectual property (IP) ownership, research suggests that information can leak to competitors via shared intermediaries (Cox Pahnke et al., 2015). While alliances with governmental partners also bear the risk of information outflows to competitors who collaborate with the same 
agencies, governments may be less inclined to behave opportunistically by leaking knowledge to competitors as they are - unlike firms — not profit-driven and — unlike universities and private research institutes — not incentivized above all to publish their research results. Overall, based on the preceding arguments, we propose a fourth hypothesis:

Hypothesis 4: For startups in the cleantech sector, technology development alliances with government organizations are more positively associated with private financial investments in the startup when compared to other alliance partners.

\section{Dataset and Methods}

\subsection{Data and measures}

\subsubsection{Description of the U.S. cleantech startup dataset}

To test the hypotheses, we constructed a novel and unbalanced panel of 657 startups in the cleantech sector between 2008 and 2012. The panel includes 2,015 alliances (2008 to 2012) of all U.S. startups interacting with other firms, government organizations, research institutes, universities, and other not-for-profit organizations from the U.S. and globally (see Section 3.2.1 for details).

The startups operate in one or more of the following 17 sub-sectors: solar, wind, biomass, geothermal, hydro and marine power, nuclear, energy storage, smart grid, energy efficiency, advanced materials, transportation, biofuels and biochemicals, conventional fuels, fuel cells and hydrogen, air, recycling and waste, or water and wastewater. We considered a firm to be a startup if it is younger than 5 years in year $t$, with $t_{0}$ being 2008. 66 percent of the startups were founded before $t_{0}$, and 34 percent entered our sample during the reported period. It provides very granular 
and time-resolved information about the type of startup partner, the type of startup alliance, and basic firm information regarding size, age, location, and sector.

We assess the outcomes of alliances that took place in 2008-2012, i.e., following the global financial crisis of 2007-2008. In this period, government recovery programs like the American Recovery and Reinvestment Act of 2009 provided support for cleantech and other sectors while private sector VC transactions in 'hardware' cleantech startups remained high (Anadon et al., 2017). ${ }^{5}$ We overall capture a period of thriving public and private resources for startups. To ensure that our results are robust to the variation of resources in our dataset during the period of evaluation, we include year fixed effects (2008-2012) in all of our statistical models.

We obtained the base data on the alliances of U.S. cleantech startups from the i3 Cleantech Group database. This relatively new database has hardly been used for research purposes in the past (see Zobel et al., 2016, for an example in the US solar industry) and is, to the best of our knowledge, the richest and most thorough collection of information on the global cleantech sector. It applies various mechanisms to collect information on firms, alliances between firms, industry development, and investments and this information is regularly updated and checked either by a research team or directly by the firms (i3 Cleantech Group, 2015). Information on alliances includes the names of the partners, alliance types, a brief description of the purpose and goal of the alliance, and the source. Furthermore, information for all potential types of partners is collected using the same method, which implies that alliances with government organizations are certainly not

\footnotetext{
${ }^{5}$ Some of this government support included significant increases in DOE funding for applied R\&D programs in the cleantech space, including work in the laboratories. In particular energy R\&D funding for the technologies included in our cleantech database (i.e., renewable power, bioelectricity and biofuels, industrial, buildings and vehicle efficiency, transmission, distribution and storage) increased from around \$1.0 billion in 2008 to \$3.9 billion in 2009 (spent over two years), with appropriations in 2010 and 2011 stabilizing around $\$ 1.5$ billion and in later years to $\$ 1.7$ billion (Anadon et al., 2017).
} 
overrepresented in the sample. i3 Cleantech Group provided us with the startup names and alliance information for the whole cleantech sector.

Two researchers in our team independently conducted manual verifications of all pieces of information covered by the database. We further expanded our dataset to include detailed information for each startup on location, patents, and financial investments by using multiple data sources (e.g., Orbis, FactSet, Thomson One, Derwent Innovation Index). As a result of this triangulation, we are reasonably confident that our sample of U.S. cleantech startups is comprehensive and does not systematically exclude particular types of startups collaborating in technology development and licensing (i.e., there is no selection bias in the startups included in the sample). Details on each of these independent and dependent variables, and how they were operationalized for our statistical analysis, are described in the next Sections 3.2-3.4. To examine the impact of the type of partner and the type of alliance on the dependent variables (innovation activity and financial investments), we used the Stata (14) software.

\subsection{Independent variables}

\subsubsection{Type of partner}

Startups can collaborate or set up alliances with different types of partners. As described in Section 3.1, we categorize these partners into five categories: other firms; government organizations, laboratories, or agencies; universities and private research institutes; NGOs or environmental groups; and other public partners. These different partners of U.S. cleantech startups types include organizations from the U.S. and as well as from other countries.

Again, two researchers in our team independently coded all of the startup partners by using additional information such as webpage research of the respective partner. In doing so, the 
researchers coded government organizations as those public agencies with the goal to advance technological innovation and to contribute to technology transfer in the energy space either through funding, conducting, or supporting R\&D (Anadon et al., 2016; Bin-Nun et al., 2017; Goldstein and Narayanamurti, 2018). In contrast, public and private universities and private research institutes constitute a separate category. In the rare case of inconsistent coding between the two researchers, additional webpage checks helped for reaching consensus. This independent exercise of doublecoding partners resulted into (i) 2,093 firms (803 young cleantech firms (younger than 10 years) and 1,290 other private sector businesses), (ii) 54 government organizations (e.g., DOE, DoD) and governmental laboratories or agencies (e.g., NREL, Fraunhofer), (iii) 78 universities (e.g., MIT or Princeton University) and private research institutes (e.g., Rocky Mountain Institute), (iv) 9 NGOs or environmental groups (e.g., Sierra Club), or (v) 43 other public partners (e.g., cities or schools). We attached the full list of non-firm partners to allow replicability of our findings in the attached Supplementary Information (SI) file.

\subsubsection{Type of alliance}

We built on the initial classification of the type of alliance provided in the i3 Cleantech Group database to develop our research. Two researchers in our team independently assessed the description provided by the i3 database and classified the alliances into five different types: technology development, licensee (i.e., when the startup obtains the license), procurement alliance, licensor (i.e., when the startup provides the license), and project development alliances (see Table 2). This independent exercise of double-coding alliances into different types resulted in the recoding some of the classifications to ensure a consistent matching of the 2,015 alliances (2008 to 
2012). We used technology development and licensee as the independent variables and used the rest of the types of alliances as controls. ${ }^{6}$

Insert Table 2 about here

\subsubsection{Duration of alliances}

Estimating the duration of various alliances in our database was necessary for fully understanding their impact. Even though alliances between partners typically last for more than one year, duration data is rarely reported. Prior research based on networks of established firms has assumed durations of between one and five years, relying mostly on three years (e.g., Choi and Anadón, 2014; Schilling and Phelps, 2007). In contrast, we took a more conservative approach for our startup context and tested the robustness of our results to different assumptions regarding the average duration of alliances: either two years (i.e., 2008-2009, .., 2011-2012) or three-years (i.e., 2008-2010, .., 2010-2012). We used these two- or three-year moving windows for annual measures to account for the impact of prior (including pre-sample) alliances and their cumulative nature (Robinson and Stuart, 2007; Schilling and Phelps, 2007). Given that the two-year duration is more relevant in the short-term oriented context of startups, we report the results on the two-year duration of the alliances in Section 4.

\subsubsection{Network measures for alliances}

We used the network measure of degree centrality to illustrate patterns in each two-year window for each type of partner and type of alliance. The degree centrality for each startup captures the number of connections of a particular node (firm). We counted the number of alliances for each

6 Please note that we briefly discuss the results on these additional alliance types, especially between startup outcomes and procurement alliances, in Section 5. 
two-year window in two ways: (i) we counted the number of alliances for each type of partner, and (ii) more granularly, we counted the type of alliance per type of partner (see Figure 2 for an overview of governmental partners and Figure 3 for the overall network). ${ }^{7}$ By counting the number of alliances, degree centrality is the simplest network measure that allows more intuitive interpretation of results. We checked the validity of the degree centrality measures by also evaluating eigenvector centrality as another important network measure. Eigenvector centrality captures patterns in a broader network by assigning weights to each alliance based on the centrality measures of the partner (Bonacich, 2007). An alliance with a well-connected partner in the strongest network thus has a higher weight than alliances with a weakly-connected partner (Bonacich, 1987; Schilling and Phelps, 2007). We provide the (almost identical) results for eigenvector centrality in the SI file (see Table 7 in SI file), but focus on degree centrality in the following for reasons of simplicity. We used the "igraph" package in R to calculate these network measures (Csardi and Nepusz, 2006; R Core Team, 2015).

Insert Figure 2 and 3 about here

\subsection{Dependent variables}

\subsubsection{Patenting activity}

To examine the impact of different types of partners and alliances on startup innovation activity, we use patents as a measure of technology innovation (or technological change) that is validated in an external examination process (Griliches, 1990). Although using patents to measure innovation activity or knowledge creation is not without challenges - for example, the propensity to

\footnotetext{
${ }^{7}$ For example, when a startup was engaged in a technology development alliance with one government partner and three firms in 2010 and had no alliances in 2011, the measure for government technology development alliances for the specific startup is one for 2010 and 2011; and for startup alliances with firms it is three for 2010 and 2011.
} 
patent and overall patenting activity might vary between industries (Levin et al., 1987) — it is a commonly used measure of innovation in the context of startups (e.g., Clarysse et al., 2014; Howell, 2017). This seems to be particularly true in our empirical setting as the patenting propensity of U.S. cleantech startups has been found to be very high. Patents are generally more important in sectors with longer product life cycles (e.g., energy) when compared to more dynamic sectors (e.g., IT). In contrast to established firms, startups experience more challenges when innovating, where knowledge outflows do not only reduce profit levels but can threaten their survival. This is because startups typically depend on single products or services and cannot rely on a product portfolio for securing their survival. Therefore, the relatively cheap and standardized process to secure knowledge in the form of patents might be important to resource-constrained startups. In addition, patents can be a means to overcome the so-called 'liability of newness' in providing important signals to potential investors and helping in securing private funding (Booker et al., 2012; Conti et al., 2013; Hsu and Ziedonis, 2013). Thus, given the newness and stronger vulnerability, cleantech startups have an inherent interest to secure their innovative knowledge, which is why patenting activity represents a relevant measure for startup innovation.

We use the number of patent applications for firm $i$ in year $t$ as a proxy for innovation efforts. As we discuss in Section 3.4.4, we also report the statistical results controlling for the 17 subsectors to account for differences in patenting propensity and potential variation in patent value across cleantech sub-sectors (Trajtenberg, 1990). The annual patent applications were extracted from the Derwent Innovations Index database in their year of priority application.

To further assess the robustness of our analysis for alternative measures of innovation that might better account for innovation quality, we collected patent forward citation data. We extracted the total citations for the patent applications of each firm using The Lens open-source patent database until September 2018. As shown in Table 1 in the attached SI file, the results using patent 
citations instead of patent counts are almost identical. We also calculated the same models by including a linear depreciation of 1 based on the linear decreasing graph of U.S. patent citation over time from Jaffe and Trajtenberg (1996), as well as an annual 10\% and 20\% decrease, which again provided almost identical results to the models without depreciation. ${ }^{8}$ Given the importance and experience of using patenting activity as a measure of startup innovation, the fact that patenting itself is seen as an important outcome to attract investments, and considering some of the disadvantages of patent citations (e.g., dependence on examiner (for a recent overview and best practices, see Jaffe and de Rassenfosse (2017)), we focus on patenting activity in the following sections.

\subsubsection{Private financing deals}

We used the number of annual financing deals that each startup acquired per year to evaluate the signaling effects of alliances on investors. Financing deals are regularly applied to measure performance effects of startups because alternative measures such as employee or sales growth are often not available or informative as a result of the startups' newness. This outcome variable is especially relevant in studies on distinct strategies for startups to leverage the likelihood of attracting investments and to evaluate which of these actions serve as relevant signals to investors (see, for example, recent research by Howell (2017); Islam et al. (2018); Kerr et al. (2014)). The financing deals were collected and aggregated from the Thomson One, FactSet, and i3 Cleantech Group databases, and primarily encompassed VC funding at different stages (seed, series A, B, etc.) as well as other private investments (loans, bonds, etc.). To assess the robustness of the financing deals variable and to rule out potential concerns of including less successful startups with many but smaller financial rounds, we collected data on the investment amounts in USD per deal. We were

\footnotetext{
8 These results are available upon request from the authors.
} 
able to obtain information for $72.9 \%$ of the financing deals included in our sample. ${ }^{9}$ The positive and highly significant correlations between investment deals and (a) total investment amount, (b) average investment amount, (c) average amount divided by firm size (see SI file, Table 2) provide support for our chosen variable.

We further included a measure of firm growth to check the robustness of the private financing deals variable. We measured firm growth as the likelihood of achieving a desired growth outcome, i.e., an IPO or an acquisition (excluding bankruptcies or liquidity constraints), within six years after the startup was founded (e.g., applied by Guzman and Stern, 2015). The data on firm growth was collected from various sources, including the i3 Cleantech Group and the FactSet database, and manually verified through a web search. Growth was operationalized as a binary variable equaling 1 for an acquisition or IPO in year $t$, and 0 otherwise.

\subsection{Control variables}

\subsubsection{Pre-sample patents}

To account for the diminishing importance of earlier knowledge, we included the pre-sample patent stock as a control variable, annually depreciated at a rate of 15 percent (e.g., Popp, 2004; Qiu and Anadon, 2012). Following Schilling and Phelps (2007), we included the annually depreciated value of pre-sample patents (before 2008) to control for unobserved heterogeneity in firm patenting activity.

\subsubsection{Prior private financing deals}

We controlled for the impact of private investments by including the number of prior financing deals of each startup for each year. We applied an annual depreciation rate equal to the

\footnotetext{
9 Information on the magnitude of financing deals is inherently sensitive, which is why it is often not consistently available-in
} contrast to the general information that a deal has been acquired (Howell, 2017). 
one we used for prior patents (i.e., 15 percent) to account for the diminishing importance of financial investments over time.

\subsubsection{Prior public financing deals}

Similar to measuring prior private financing deals, we included a measure that accounted for whether the startup received prior grants or other forms of financial support from public sources. As an additional robustness check and acknowledging the central role of the DOE, we compiled information on the number of DOE grants or other types of financial support that the startups might have received in the examined period. We obtained the data from the USA Spending database and counted the number of financing deals per startup. Overall, 78 of the 657 cleantech startups in our sample (i.e., 12 percent of our sample) had received one or more DOE grants or other forms of financial assistance (including direct payments or reimbursements). The two variables show a positive, highly significant correlation $(r=0.054$, $p$-value $=0.002)$.

\subsubsection{Sub-sector, age, and size}

We extracted firm-level information on sub-sector, age, and size from the i3 Cleantech Group, FactSet, and Orbis databases, and complemented and verified all information in a web search. We included industry fixed effects for the 17 sub-sectors in our statistical models. Figure 4 shows the average number of patents per sub-sector. We measured firm size by the number of employees, and age by including the time interval since the founding year.

Insert Figure 4 about here 


\subsubsection{Location}

We accounted for the geographic location of the U.S. cleantech startups, particularly in regional hotspots. For example, the Silicon Valley and San Francisco area are together home to 158 of the 657 (i.e., 24 percent of our sample) cleantech startups. We examined whether firms that are located in geographically dense areas have higher propensities to innovate or to attract financial investments. We collected information on firm addresses from the i3 Cleantech Group, FactSet, and Orbis databases, and mapped the zip codes to the respective Metropolitan Statistical Area (MSA) for 2011. We captured the variance in the concentration of cleantech startups in the different MSAs by using the percentage of total firms located in the respective MSA (for a similar approach, see, for example, DeCarolis and Deeds, 1999; Folta et al., 2006). As shown in Figure 5, around 40 percent of the firms are located in the San Francisco-Oakland-Fremont, Boston-Cambridge-Quincy, New York-Northern New Jersey-Long Island, San Jose-Sunnyvale-Santa Clara, and Los Angeles-Long Beach-Anaheim regions, and the rest of the firms are spread across the country or located in smaller regional hubs. As expected, the San Jose-Sunnyvale-Santa Clara area is among the highest in average patents per firm.

Insert Figure 5 about here

\subsection{Robustness checks}

We address potential concerns that some of the effects we estimate on the impact of partnering with governments on patenting activity and financial investments are driven by those firms that have higher 'ability' through quantitative and qualitative arguments. Quantitatively, we assess the robustness of our results using an instrumental variable regression (IV) analysis with the membership of U.S. Senators and Congressmen that represent the Congressional District or State of 
the startup in relevant cleantech (Sub-) Committees as an instrument for government alliances (Gruber and Hungerman, 2007; Knight, 2002; Stock and Watson, 2007). In addition, we use propensity score matching (PSM) based on age, size and location (Abadie and Imbens, 2016). The two empirical strategies are briefly discussed in Section 4.2 and described in detail in the SI file.

We also point out qualitatively that our results are less prone to endogeneity concerns because of the arguments that governments (a) should not try to pick winners to secure their own funding prospects and (b) might not have the ability to do so even if they wanted to.

Government organizations have an inherent interest to promote energy innovation by partnering with a broad set of private partners — and not just the most successful ones — because if they are perceived as stepping too far into applied R\&D (doing things that are not risky enough and that the private sector or other investors would be supporting anyway), they are likely to face backlash in Congress and funding cuts. A statement from the Chairman of the U.S. House Committee in Science, Space and Technology in 2015, Rep. Lamar Smith is representative of the concerns of the legislative branch regarding picking winners: "over the last decade, there has been unjustified growth in spending on late stage commercialization efforts within EERE. This bill refocuses DOE's work on basic R\&D efforts, not subsidies” (Ling, 2015). Some at DOE and elsewhere believe that, in spite of the technology transfer mandate, there needs to be some disconnect between DOE and the private sector, arguing that the laboratories first purpose is to serve the needs of basic research and to establish a shared knowledge base, making it inappropriate for the laboratories to only provide support for a private sector interested in proprietary knowledge with only privately appropriable benefits. Interviews discussed in Logar et al. (2014) show that this need to balance is very present in minds and decisions about time and effort allocation of the scientists in government organizations. 
Furthermore, recent research on the impact of government subsidies has found that they are additional to startups but lead to a substitution for larger firms or in the context of subsequent larger grants after the more binding resource constraints are removed (Howell, 2017; Pless, 2018). Howell (2017) further found in a regression discontinuity design on ranked applicants to the Small Business Innovation Research (SBIR) grant program, that the rankings in small firm funding rounds were not predictive of their subsequent outcomes. This indicates that even if government organizations would try to pick winners, they might not have the ability to do so when controlling for observable characteristics (e.g., prior patents, financing deals).

\section{Results}

\subsection{Main findings}

A summary of the descriptive statistics for the 657 startups in our sample, averaged over time, is provided in Table 3 and of the correlations in Table 4. Our dependent variables (patenting activity and financing deals) are not highly correlated with any of the other variables. The startups in our sample introduced an average of 1.40 patents every year and, on average, attracted more than one financing deal every two years (mean $=0.64$ per firm-year). Overall, while all our startups had alliances in at least one of the four two-year windows (2008-2009, .., 2011-2012), 13.52 percent of the startups collaborated with at least one government organization.

Insert Tables 3 and 4 about here

We analyze the data with negative binomial regressions for the count variables—patenting activity and financing deals - because of overdispersion. We use robust standard errors and include time and sector fixed effects in our models. For each outcome variable, we calculated three different 
models: Models 1 and 2 for the overall impact of the controls and partner type variables respectively, and Model 3 for the granular separation in alliance types per partner. The estimates for industry and time period effects are, although estimated, not reported to conserve space. Table 5 reports the estimated coefficients of the negative binomial regression models on patenting activity and on private financing deals. Overall, the results for patenting activity in Model 2 indicate that compared to alliances with all other types of partners (i.e., universities or research institutes, notfor-profit partners, other public organizations, and other startups or established firms), only alliances with government organizations are significantly associated with higher startup patenting activity $(\beta=0.284, p$-value $=0.047$, Model 2$)$. As negative binomial regressions model the log of incident counts, this estimate implies that one additional alliance with a governmental partner is associated with a 32.9 percent increase in patenting activity $\left(\operatorname{IRR}=1.329, \mathrm{e}^{\beta}\right)$. Model 3 provides the results for the hypotheses.

Licensing alliances with governmental partners are not more strongly associated with patenting activity, which is why we do not find support for Hypothesis 1 (H1). As hypothesized in $\mathrm{H} 2$, we found that technology development alliances significantly increase patenting activity $(\beta=$ 0.552, p-value $=0.010$, Model 3), which is the strongest increase when compared to technology development alliances with firms $(\beta=0.218, p$-value $=0.000$, Model 3$)$ and universities and private research institutes (not significant). This implies a 73.7 percent increase in patenting activity with every additional governmental technology alliance $(I R R=1.737)$ compared to a $24.4 \%$ increase with every firm technology alliance $(I R R=1.244)$. Licensing alliances with government partners are associated with strongest increases in financing deals $(\beta=0.935, \mathrm{p}$-value $=0.009$, Model 3$)$ when compared to licensing alliances with firms (not significant) and universities and private research institutes (not significant), suggesting support for H3. Every additional license from a governmental agency is associated with a 155 percent increase in financing deals (IRR $=2.546$ ). 
Even though the association between government technology alliances and financial deals is positive, it is not significant, which does not support $\mathrm{H} 4$.

\section{Insert Table 5 about here}

\subsection{Additional analysis}

To check the robustness of our results and to rule out alternative explanations, we specified several alternative econometric models that revealed similar results, which are included in the SI file. Models using patent citations instead of patent activity revealed almost identical results (see Table 1 in SI file), highlighting the importance of government technology alliances for patent citations of the startups. Moreover, a binary variable to test whether the startups achieved a growth outcome (IPO or acquisition within 6 years after founding) in a logit regression revealed similar results to the private financing deals models (see Table 8 in SI file). We further tested eigenvector centrality as a more complex alternative network measure for degree centrality (i.e., the network measure we applied to calculate the alliances of startups as described in Section 3.2.4), which also revealed similar results for both outcome variables (see Table 7 in SI file).

Furthermore, as indicated in Section 3.5, we applied two additional strategies to address potential concerns of having better firms (which may have better innovation outcomes anyway) partner more with government organizations. These strategies (IV and PSM) are briefly described below and in more detail in the SI file.

We used the binary variables, House and Senate members of the startups' Congressional District (House) or State (Senate) per year as instruments for governmental alliances and calculated IV OLS regressions to test instrument relevance and exogeneity. We performed a Durbin and WuHausman test of exogeneity after the 2SLS regression. Both tests are insignificant (see Table 4 in SI 
file), which indicates that our variables are exogenous (e.g., Baum et al., 2003). However, the FStatistic for evaluating the strength of the instrument is 3.45 for patenting activity and 3.51 for financial deals (see Table 3), indicating that committee membership is a weak instrument (Stock and Watson, 2007). Because our two dependent variables (patenting activity and financial deals) are count variables, we ran instrument Poisson regressions to test the impact of government alliances on patenting activity and financial deals (see Table 5 in SI file). The results confirmed the significant positive association of an alliance with a governmental partner for patenting activity $(\beta=1.508, \mathrm{p}$ value $=0.017)$ and financial deals $(\beta=1.574, \mathrm{p}$-value $=0.001)$.

We further conducted PSM and tested the treatment effect on similar firms based on age size, and location. Our findings indicate significant Average Treatment Effects on the Treated (ATET) (p $<0.1)$ for patenting activity and for private financing deals $(\mathrm{p}<0.01)$ (see Table 6 in the SI file). These findings again point to the importance of government partners for cleantech startups. Because PSM is only as good as the matching variables and potential confounding factors are not addressed, we only use it as a robustness check which should provide similar findings (Barth et al. (2007); Li (2012); Stone and Rose (2011)).

However, while both empirical strategies are valuable as robustness checks because they provide similar findings, we cannot fully rule out potential selection concerns given the fact that we have a weak IV instrument and that PSM is dependent on the matching variables. We discuss the implications of the possible identification concerns in the limitations section. 


\section{Discussion}

Our study highlights the unique resources of government partners for cleantech startup innovation and ability to attract financial investments. In doing so, we focus on the valuecreation mechanisms of network resources from governments, universities and private research institutes, and private sector firms for startup outcomes. Overall, our findings contribute to the emerging research on entrepreneurial ecosystems and extend the alliance perspectives on innovation in the following ways.

First, our findings complement existing research on entrepreneurial ecosystems with RDT that highlights the importance of alliances for partially absorbing dependencies of their environment. We apply RDT typologies of resources to the U.S. cleantech space and suggest an important theoretical lens for determining top or "anchor" partners that are associated with increased entrepreneurial innovation. RDT's focus on organizations' management in the context of external relations that ensures access to the most valuable resources offers us avenues to understand which type of partner possesses the most important physical, technological, and social resources that are associated with the highest levels of startup innovation and financial investments (Pfeffer and Salancik, 1978). Our findings highlight alliances with governmental organizations are importantgovernmental partners hold critical technological and physical resources in the cleantech sector due to the longer term perspective for their research activities, substantial and energy specific research experience, physical equipment, and dedicated researchers. These resources are highly complementary to the abilities of startups in rapidly identifying and responding to market opportunities using jointly developed technologies. In general, greater resource complementarity of partners can widen power imbalance and weaken the outcome of the smaller alliance partner (Casciaro and Piskorski, 2005; Lavie, 2007). However, in the case of government organizations as partners, the tradeoff between resource complementarity and power imbalance delivers stronger 
positive impact due to the government organization's missing profit-orientation and their mandate to promote (energy) innovation and technology transfer. Combined with the reduced concerns of appropriability and opportunistic behavior, these unique characteristics make governments key, yet so far undervalued, partners. Our results on the value of alliances with governmental partners, i.e., licensing for financial investments and technology development for patenting activity, provide empirical support for the idea that governments can be valuable as partners for generating innovation and represent valuable signals of venture quality to potential investors.

Second, our theory and empirical evidence enable important insights for RDT into the role of interorganizational alliances with partners that are characterized by high resource complementarity and low power imbalance to absorb the dependencies of the environment — an area that, unlike mergers \& acquisitions (M\&A), has been relatively understudied (Xia et al., 2016). Although our results suggest the strongest effects of startups' alliances with governments, we also find that other partners - i.e., universities and private firms - are important for innovation. For universities, we find that licensing alliances are important for startup innovation. The results on licensing alliances likely result from the increased focus on improving technology transfer offices at major research universities which reduces friction for these alliance types (Siegel et al., 2007). Moreover, the larger diversity of university researchers when compared to government researchers may enable more tailored activities and technical competencies at least of a sub-set of the researchers, which are more closely related to those of startups (Sá and Litwin, 2011). The weaker effects of technology development alliances with universities than with governments could be explained by the following three reasons: (a) universities typically possess more limited resources for technology transfer offices to reduce information asymmetries (there are of course some notable exceptions like MIT and Stanford); (b) universities typically provide limited incentives for researchers to devote more time to work with the startups to make the most of the development partnership; and (c) universities 
do not possess the wide-range of physical resources such as research and testing facilities or equipment that external firms with limited resources, especially startups, can use from governmental organizations (Koonin and Gopstein, 2011). For private sector firms, we find that technology development alliances contribute to increased innovation activities and financial investments, although to a lesser extent than technology development or licensing with governmental partners. While private sector investors might reward a technology development alliance with a private firm more than with a governmental partner (perhaps because of the perception that private firms may work on products that are more attuned to market needs and with more immediate returns), the unique technological expertise of governmental partners in some areas, combined with reduced power imbalance as well as concerns of appropriability and opportunistic behavior may explain the stronger innovation effects we detect for government alliances. Overall, these findings on the granular effects of alliance types with different ecosystem partners and the importance to consider resource complementarity and power imbalance resonates with recent calls from Guzman and Stern (2015) to focus on studying the "quality" of entrepreneurial outcomes rather than just the existence of startups and other actors for evaluating ecosystem effectiveness.

Third, the granular perspective on network resources from governments for cleantech startup innovation complements existing research on the role of governments in financing R\&D or through other technology-push or demand-pull policies (discussed in Section 1). Governments help create the market environment and demand for commercialization of products or services of startups through demand-pull policies, or they engage in financing of R\&D through grants to help to overcome the underinvestment in energy research through technology-push (Bettencourt et al., 2013; Choi and Anadón, 2014; Doblinger et al., 2016; Hoppmann et al., 2013; Howell, 2017; Nemet, 2009; 2018; Schmidt and Sewerin, 2018). We show that there is an important role for direct 
technology-based alliances between governments and startups for increased startup innovation activity. This promotion of innovation in 1:1 alliances is additional and complementary to the technology-push and demand-pull incentives from governments. In this sense, the additional benefit of an alliance when compared to a quota obligation or other demand-pull policy incentives is that alliances only provide the outlined benefits (such as access to complementary resources) to the specific firms that are engaged in the alliance, whereas demand-pull policies typically work for all firms. Compared to the financing of $R \& D$, the interaction and resource exchanges between the two partners in a technology development alliance is much more intense because of the interest in joint progressing of innovation or application. The differences between these policy incentives and alliances can further be explained by applying insights from TIS research (e.g., Bergek et al., 2008; Hekkert et al., 2007). Demand-pull and technology-push policies represent institutions that help steer effective system development and analyses of TIS, whereas the examined direct alliances between governments and startups relate to interactions between actors and the (organizational and network) resources (Musiolik et al., 2012). Our findings thus provide granular evidence on the importance of organizational and network resources for promoting cleantech innovation through interactions between startups and governments as actors in the system, and not between institutions and actors.

Fourth, our study further contributes to research on interorganizational alliances by acknowledging that startups have more limited resources than other firms, and that collaborating with diverse partners is a resource intense endeavor. By building on the value-creation mechanisms of network resources provided by the extended resource-based view (Lavie, 2006, 2007), our findings help to understand how startups can benefit from direct access to complementary assets, synergies and legitimacy from network resources. These findings provide "fine-grained items for each of the possible knowledge channels" (Laursen and Salter, 2006: 147), enabling an evaluation 
of the distinct benefits of alliances with governments through codified and tacit forms of knowledge exchange, possibilities of spillovers, and signaling effects. We find that access to more implicit and tacit knowledge sources from technology development alliances is more important for subsequent innovation activities than direct access to codified knowledge from public licensing. However, the latter is associated with an increased likelihood of attracting financial investments. Overall, this seems to reflect that investors reward a technology 'in hand' more than a technology development alliance. In addition, we find no significant innovation or signaling effects from procurement alliances with governmental partners. Our results do not reflect the implicit learning opportunities that have been claimed to be prevalent in procurement alliances (e.g., Malecki and Poehling, 1999; Von Hippel, 1978) potentially because governmental partners typically serve as customers and not as suppliers of technologies to startups (Bonvillian and Atta, 2011; Fuchs, 2010).

Finally, by building on Lavie's (2007) three value-creation mechanisms to understand how startups can access complementary resources, we follow the research call from Hillman et al., (2009) to advance RDT applications by using a synthesized approach between RDT and the resource-based-view for understanding the impact of alliances for increased startup innovation and financial investments. The application of this synthesized approach combined with the quantification of the relationship between startup alliances with different partners and startup outcomes offers important insights into "how obtaining control of critical resources offers firms competitive advantage and how developing resource interdependencies around critical resources affect the advantage derived from them" (Hillman et al., 2009: 1417). 


\section{Policy implications}

Our results inform policymakers in how governments and governmental organizations can effectively engage with startups and investors to promote the cleantech sector and engage in the entrepreneurial ecosystem through polices that extend beyond technology- and demand-pull.

The most recognizable way in which governments support startups and small firms is through direct financing - for example, the U.S. SBIR is administered through agencies (such as DOE and DOD) that are mandated to allocate part of their budget to support innovative small firms that are relevant to their objectives (Audretsch, 2003; Howell, 2017). We show that, in addition to financing, government organizations such as the national laboratories can also directly partner with resource-constrained startups and support entrepreneurial activity. We show that in the U.S. cleantech sector licensing out technology to a startup can help the latter attract financial investments, and that developing technology jointly with a startup can support subsequent patenting activity by the startup. This leads to the identification of new technology opportunities and supports in shaping and steering the development of technologies in the energy sector towards meeting local environmental as well as global climate and sustainability goals.

Previous work had identified the value of long-term and relatively stable funding and the importance of close integration of R\&D and use (e.g., the support for military technologies in DARPA, the long-term research in Bell Labs) (Bonvillian, 2014; Narayanamurti and Odumosu, 2016; Riordan and Hoddeson, 1998). In this sense, our analysis has important implications for government agencies themselves. In particular, it suggests the need to test additional incentives in government organizations active in energy innovation to support collaborative technology projects between centralized research organizations and decentralized, geographically dispersed firms (e.g., Martin, 2016). Such incentives may include investing more in technology transfer capabilities in 
research organizations (Chan, 2015), entrepreneurs in residence programs, models based on the Cyclotron program at Lawrence Berkeley laboratory (Cyclontronroad, 2018), allowing government scientists to take temporary leave to work with a private firm (Anadon et al., 2016). Such additional incentives for joint development and technology transfer would reduce the information asymmetry and provide incentives to researchers. Government agencies can further gain vital inputs on applying unconventional approaches to solving current technological problems through these direct alliances with agile, flexible startups. This implies that government agencies could mimic the motivation and activities of large firms that engage with startups to escape the dominant paradigms and to creatively solve current problems (Benson and Ziedonis, 2009; Dushnitsky and Lenox, 2005). Such an evaluation of how technology alliances with startups and additional incentives may leverage increased innovation on the side of the government organizations would represent an exciting avenue for future research.

The benefits of additional efforts to promote alliances between government organizations and cleantech startups in the U.S. could further extend beyond geographical hubs—our findings show that alliances with strong innovation outcomes (i.e., technology alliances between startups and centralized governmental laboratories such as NREL in Golden, Colorado, see Figure 2) were outside of regional hubs such as Silicon Valley. Our results point to the value of collaborations between key government partners - especially those with expertise and resources in energy technologies_ — and small firms outside of regional ecosystems.

The strong relationship between government technology alliances (when compared to other firms or universities) and improved cleantech innovation outcomes further informs current debates regarding proposals to cut funding for public research organizations in energy (Anadon et al., 2017). Our findings on the importance of governmental licensing alliances to attract financial investments for startups complement the notion that government support for R\&D in small firms 
does not crowd-out private financing (Howell, 2017). This suggests that government organizations that devote resources to providing information on licensing options and to facilitating a smooth licensing process (Chan et al., 2017) can help counter the challenges of VC investment in cleantech startups (Gaddy et al., 2017).

\section{Conclusion and limitations}

This study examines the impact of different types of startup alliances with government organizations on the ability of startups to innovate and to attract financial investments when compared to other partners. Following the call of Laursen and Salter $(2006 ; 2014)$, we separate the knowledge flows from technology development and licensing alliances with government organizations, research institutes and universities, and other firms. By evaluating the value-creation mechanisms of network resources from governmental partners for startups, this paper contributes to emerging research on entrepreneurial ecosystems and extends alliance perspectives on innovation. In addition, it makes meaningful contributions to ongoing policy discussions related to the role of governments in cleantech innovation. However, as with all empirical studies, ours is not without limitations.

First, we study the impact of alliances on cleantech startups located only within the U.S. Nevertheless, our findings regarding the value of different types of partners and alliances provide a relatively complete picture of the cleantech startup sector: a large majority of cleantech startups are located in the U.S, our sample comprises the whole country, and we also consider U.S. startup alliances with global partners. However, we see exciting opportunities for future research to conduct comparative studies in a different country context. Second, our study is limited to the period from 2008-2012 that followed the financial crisis of 2007-2008, where government recovery 
programs like the American Recovery and Reinvestment Act of 2009 positively affected the cleantech sector and the number of VC transactions especially in hardware-type startups peaked before stabilizing (Bumpus and Comello, 2017). We included year-fixed effects to account for these changes in our empirical models. Given that we have no startup and alliance data before 2008, we cannot evaluate the extent to which a change from fewer resources in the 2004-2008 period to more resources in the 2008-2012 period translated into a larger or smaller importance of different types of alliances and partners. Thus, our results might not be fully applicable to periods of significantly less government and private funds. This is both a limitation of our work and a very promising avenue for future research. Also, beyond the changes during 2008 to 2012, the public funding context for energy R\&D after 2012 until 2018 has not changed significantly (in spite of two attempts by the Trump administration to slash public funds for DOE energy R\&D and the national laboratories, the U.S. Congress has chosen to keep funding for these programs largely constant (Anadon et al., 2017)). Thus, our results continue to be valid and relevant from the perspective of public funding. There was a shift in VC investment after 2011 and an overall decline until 2013 (to approx. 1000 million USD) in total global early-stage energy VC investment, followed by an increase (to over 3000 million USD) after 2015 (Anadon et al., 2017; IEA, 2017). The lower funding period in the VC cleantech community could further have affected the need for firms to seek additional alliances after 2012, so if anything the centrality of government resources may have become more important for the value of alliances formed after 2012. Third, even though: (a) we included the incentives for why governments should not want to just pick winners; (b) we provided recent evidence that even if they wanted to pick winners, they might lack the ability to do so (Howell, 2017); and (c) we included two empirical strategies (IV and PSM) as robustness checks that further support our findings, there might still be concerns that some of the effects we estimate on the impact of partnering with governments on patenting activity and financial investments are driven by those 
firms that have higher 'ability.' However, our results would also support the notion that governmental alliances are valuable for better startup outcomes. Given the high costs (time and effort) of partnering with government actors (Glauthier and Cohon, 2015), highly capable firms would not make the required investments in establishing such alliances if they would not be convinced about the value to their business. Furthermore, if only successful startups partner with government organizations, our results would be valuable as signals to other startups on where to focus their strategic efforts on. Given this possibility, we are cautious about the external validity of our results to firms that may not have identified the need to partner in the first place, which could be the subject of future research.

\section{Acknowledgements}

This research was funded by the Energy Technology Innovation Policy (ETIP) group at the Belfer Center of Science and International Affairs at the Harvard Kennedy School. The authors are grateful to the i3 Cleantech Group for providing access to their database. We appreciate helpful comments from the participants at the research seminars of the Harvard Kennedy School, the Harvard Business School, the University of Maryland, the University of Cambridge, and the Grenoble Ecole de Management. We thank Dr. Nidhi Santen for connecting us with the i3 Cleantech Group, and would like to acknowledge the research support by Pepita Gigglinger and Franz Traimer. Finally, we are most grateful to Prof. Maryann Feldmann and two anonymous reviewers for their insightful comments, which significantly improved the paper. 


\section{References}

Abadie, A., Imbens, G.W., 2016. Matching on the estimated propensity score. Econometrica 84 (2), 781-807.

Adner, R., 2006. Match your innovation strategy to your innovation ecosystem. Harvard Business Review 84 (4), 98-107.

Adner, R., Kapoor, R., 2010. Value creation in innovation ecosystems: How the structure of technological interdependence affects firm performance in new technology generations. Strategic Management Journal 31 (3), 306-333.

American Academy of Arts and Sciences, 2013. Arise II: Unleashing America's research \& innovation enterprise, Accessed September 10, 2018: http://www.amacad.org/content/publications/publication.aspx?d=1138.

Anadon, L.D., 2012. Missions-oriented RD\&D institutions in energy between 2000 and 2010: A comparative analysis of China, the United Kingdom, and the United States. Research Policy 41 (10), 1742-1756.

Anadon, L.D., Bunn, M., Narayanamurti, V., 2014. Transforming US energy innovation. Cambridge University Press: Cambridge, UK.

Anadon, L.D., Chan, G., Bin-Nun, A.Y., Narayanamurti, V., 2016. The pressing energy innovation challenge of the US national laboratories. Nature Energy 1 (10), 16117.

Anadon, L.D., Gallagher, K.S., Holdren, J.P., 2017. Rescue US energy innovation. Nature Energy 2 (10), 760-763.

Arora, A., 1995. Licensing tacit knowledge: Intellectual property rights and the market for knowhow. Economics of Innovation and New Technology 4 (1), 41-60.

Audretsch, D.B., 2003. Standing on the shoulders of midgets: The U.S. Small Business Innovation Research program (SBIR). Small Business Economics 20 (2), 129-135.

Audretsch, D.B., Keilbach, M.C., Lehmann, E.E., 2006. Entrepreneurship and economic growth. Oxford University Press: New York, USA.

Autio, E., Kenney, M., Mustar, P., Siegel, D., Wright, M., 2014. Entrepreneurial innovation: The importance of context. Research Policy 43 (7), 1097-1108.

Bae, J., Gargiulo, M., 2004. Partner substitutability, alliance network structure, and firm profitability in the telecommunications industry. The Academy of Management Journal 47 (6), 843-859.

Barth, R.P., Shenyang, G., McCrae, J.S., 2007. Propensity score matching strategies for evaluating the success of child and family service programs. Research on Social Work Practice 18 (3), 212-222.

Baum, C.F., Schaffer, M.E., Stillman, S., 2003. Instrumental variables and GMM: Estimation and testing. Stata Journal 3 (1), 1-31.

Baum, J.A.C., 1996. Organizational ecology, in: Clegg, S., Hardy, C., Nord, W. (Eds.), Handbook of organization studies. SAGE: London, pp. 77-114.

Baum, J.A.C., Calabrese, T., Silverman, B.S., 2000. Don't go it alone: Alliance network composition and startups' performance in Canadian biotechnology. Strategic Management Journal 21 (3), 267-294.

Benson, D., Ziedonis, R.H., 2009. Corporate venture capital as a window on new technologies: Implications for the performance of corporate investors when acquiring startups. Organization Science 20 (2), 329-351. 
Bergek, A., Jacobsson, S., Carlsson, B., Lindmark, S., Rickne, A., 2008. Analyzing the functional dynamics of technological innovation systems: A scheme of analysis. Research Policy 37 (3), 407-429.

Bettencourt, L.M.A., Trancik, J.E., Kaur, J., 2013. Determinants of the pace of global innovation in energy technologies. PloS one 8 (10), 1-6.

Bettis, R.A., Hitt, M.A., 1995. The new competitive landscape. Strategic Management Journal 16 (1), 7-19.

Bin-Nun, A.Y., Chan, G., Anadon, L.D., Narayanamurti, V., Maxted, S.J., 2017. The Department of Energy National Laboratories, Belfer Center for Science and International Affairs, Harvard Kennedy School. Accessed September 10, 2018:

https://www.belfercenter.org/sites/default/files/files/publication/enrp-stpp-lab-report-final1.pdf.

Boccanfuso, A.M., 2010. Why university-industry partnerships matter. Science Translational Medicine 2 (51), 1-4.

Bonacich, P., 1987. Power and centrality: A family of measures. American Journal of Sociology 92 (5), 1170-1182.

Bonacich, P., 2007. Some unique properties of eigenvector centrality. Social Networks 29 (4), $555-$ 564.

Bonvillian, W.B., 2014. The new model innovation agencies: An overview. Science and Public Policy 41, 425-437.

Bonvillian, W.B., Atta, R., 2011. ARPA-E and DARPA: Applying the DARPA model to energy innovation. The Journal of Technology Transfer 36 (5), 469-513.

Booker, K., Gadgil, A., Winickoff, D., 2012. Engineering for the global poor: The role of intellectual property. Science and Public Policy 39 (6), 775-786.

Bumpus, A., Comello, S., 2017. Emerging clean energy technology investment trends. Nature Climate Change 7, 382.

Casciaro, T., Piskorski, M.J., 2005. Power imbalance, mutual dependence, and constraint absorption: A closer look at resource dependence theory. Administrative Science Quarterly 50 (2), 167-199.

Chan, G., 2015. The commercialization of publicly funded science:How licensing federal laboratory inventions affects knowledge spillovers, Harvard Kennedy School Working Paper. Available at: https://drive.google.com/file/d/0B-RCEGY3RGj7a09raGhaanhZSIU/view?pref=2\&pli=1.

Chan, G., Goldstein, A.P., Bin-Nun, A.Y., Anadon, L.D., Narayanamurti, V., 2017. Six principles for energy innovation. Nature 552, 25-27.

Choi, H., Anadón, L.D., 2014. The role of the complementary sector and its relationship with network formation and government policies in emerging sectors: The case of solar photovoltaics between 2001 and 2009. Technological Forecasting and Social Change 82 (2), 80-94.

Clarysse, B., Wright, M., Bruneel, J., Mahajan, A., 2014. Creating value in ecosystems: Crossing the chasm between knowledge and business ecosystems. Research Policy 43 (7), 1164-1176.

Clayton, P., Feldman, M., Lowe, N., 2018. Behind the scenes: Intermediary organizations that facilitate science commercialization through entrepreneurship. Academy of Management Perspectives 32 (1), 104-124.

Cohen, L.R., Noll, R.G., 1996. The future of the national laboratories. Proceedings of the National Academy of Sciences 93 (23), 12678-12685. 
Conti, A., Thursby, J., Thursby, M., 2013. Patents as signals for startup financing. The Journal of Industrial Economics 61 (3), 592-622.

Cox Pahnke, E., McDonald, R., Wang, D., Hallen, B., 2015. Exposed: Venture capital, competitor ties, and entrepreneurial innovation. Academy of Management Journal 58 (5), 1334-1360.

Csardi, G., Nepusz, T., 2006. The igraph software package for complex network research. InterJournal Complex Systems, 1695.

Cyclontronroad, 2018. Cyclontronroad: Activating tomorrow's technology leaders, Accessed November 3, 2018: http://www.cyclotronroad.org.

DeCarolis, D.M., Deeds, D.L., 1999. The impact of stocks and flows of organizational knowledge on firm performance: An empirical investigation of the biotechnology industry. Strategic Management Journal 20 (10), 953-968.

Deeds, D.L., Hill, C.W.L., 1996. Strategic alliances and the rate of new product development: An empirical study of entrepreneurial biotechnology firms. Journal of Business Venturing 11 (1), 41-55.

Demirkan, I., Demirkan, S., 2012. Network characteristics and patenting in biotechnology, 19902006. Journal of Management 38 (6), 1892-1927.

Doblinger, C., Dowling, M., Helm, R., 2016. An institutional perspective of public policy and network effects in the renewable energy industry: Enablers or disablers of entrepreneurial behaviour and innovation? Entrepreneurship \& Regional Development 28 (1-2), 126-156.

DOE, 2014. Strategic plan 2014-2018. U.S. Department of Energy, Accessed June 8, 2018: http://www.energy.gov/sites/prod/files/2014/04/f14/2014_dept_energy_strategic_plan.pdf.

DOE, 2017. America's national laboratory system: A powerhouse of science, engineering, and technology. U.S. Department of Energy, Accessed September 20, 2018: https://nationallabs.org/site/wp-content/uploads/2017/05/National-Labs-all-r.pdf.

DOE, 2018a. The history of solar. U.S. Department of Energy, Accessed March 15, 2018 : https://www1.eere.energy.gov/solar/pdfs/solar_timeline.pdf.

DOE, 2018b. National incubator initiative for clean energy (NIICE). U.S. Department of Energy, Accessed March 7, 2018: https://www.energy.gov/eere/technology-to-market/nationalincubator-initiative-clean-energy-niice-0.

Drucker, P.M., 1958. The practice of management. Harper: New York.

Dushnitsky, G., Lenox, M.J., 2005. When do incumbents learn from entrepreneurial ventures?: Corporate venture capital and investing firm innovation rates. Research Policy 34 (5), 615 639.

Dyer, J.H., Singh, H., 1998. The relational view: Cooperative strategy and sources of interorganizational competitive advantage. Academy of Management Review 23 (4), 660-679.

Folta, T.B., Cooper, A.C., Baik, Y.-s., 2006. Geographic cluster size and firm performance. Journal of Business Venturing 21 (2), 217-242.

Fouquet, R., 2013. Handbook on energy and climate change. Edward Elgar Publications: Cheltenham, UK, Northampton, MA.

Fuchs, E.R.H., 2010. Rethinking the role of the state in technology development: DARPA and the case for embedded network governance. Research Policy 39 (9), 1133-1147.

Gaddy, B.E., Sivaram, V., Jones, T.B., Wayman, L., 2017. Venture capital and cleantech: The wrong model for energy innovation. Energy Policy 102, 385-395. 
Glauthier, T.J., Cohon, J.L., 2015. Securing America's future: Realizing the potential of the department of energy's national laboratories. Accessed March 20, 2018: http://energy.gov/sites/prod/files/2015/10/f27/Final\%20Report\%20Volume\%201.pdf.

Goldstein, A.P., Narayanamurti, V., 2018. Simultaneous pursuit of discovery and invention in the us department of energy. Research Policy 47 (8), 1505-1512.

Griliches, Z., 1990. Patent statistics as economic indicators: A survey. Journal of Economic Literature 28 (4), 1661-1707.

Gruber, J., Hungerman, D., 2007. Faith-based charity and crowd-out during the great depression. Journal of Public Economics 91 (5-6), 1043-1069.

Grubler, A., Aguayo, F., Gallagher, K., Hekkert, M., Jiang, K., Mytelka, L., Neij, L., Nemet, G., Wilson, C., 2012. Chapter 24 - Policies for the energy technology innovation system (ETIS), Global energy assessment - toward a sustainable future. Cambridge University Press and International Institute for Applied Systems Analysis: Cambridge, UK, New York, USA, and Laxenburg, Austria, pp. 1665-1744.

Gulati, R., Lavie, D., Madhavan, R., 2011. How do networks matter? The performance effects of interorganizational networks. Research in Organizational Behavior 31, 207-224.

Guzman, J., Stern, S., 2015. Where is Silicon Valley? Science 347 (6222), 606-609.

Hagedoorn, J., Schakenraad, J., 1994. The effect of strategic technology alliances on company performance. Strategic Management Journal 15 (4), 291-309.

Hekkert, M.P., Suurs, R.A.A., Negro, S.O., Kuhlmann, S., Smits, R.E.H.M., 2007. Functions of innovation systems: A new approach for analysing technological change. Technological Forecasting and Social Change 74 (4), 413-432.

Henderson, R., Jaffe, A.B., Trajtenberg, M., 1998. Universities as a source of commercial technology: A detailed analysis of university patenting. Review of Economics \& Statistics 80 (1), 119.

Hillman, A.J., Withers, M.C., Collins, B.J., 2009. Resource dependence theory: A review. Journal of Management 35 (6), 1404-1427.

Hoppmann, J., Peters, M., Schneider, M., Hoffmann, V.H., 2013. The two faces of market support: How deployment policies affect technological exploration and exploitation in the solar photovoltaic industry. Research Policy 42 (4), 989-1003.

Howell, S.T., 2017. Financing innovation: Evidence from R\&D grants. American Economic Review 107 (4), 1136-1164.

Hsu, D.H., Ziedonis, R.H., 2013. Resources as dual sources of advantage: Implications for valuing entrepreneurial-firm patents. Strategic Management Journal 34 (7), 761-781.

i3 Cleantech Group, 2015. I3 cleantech database, Accessed January 11th, 2016: https://i3connect.com/front_page?ref $=\% 2 \mathrm{~F}$.

Iansiti, M., Levien, R., 2004. The keystone advantage: What the new dynamics of business ecosystems mean for strategy, innovation, and sustainability. Harvard Business School Press: Cambridge, MA.

IEA, 2017. Early-stage venture capital for energy innovation. International Energy Agency, Accessed September 25, 2018: https://www.iea.org/publications/insights/insightpublications/InsightsSeries2017Early_Stage Venture_Capital_for_Energy_Innovation.pdf.

IPCC, 2018. Global warming of $1.5^{\circ} \mathrm{C}$. Intergovernmental Panel on Climate Change, Accessed November 12, 2018: https://report.ipcc.ch/sr15/pdf/sr15_spm_final.pdf. 
Islam, M., Fremeth, A., Marcus, A., 2018. Signaling by early stage startups: US government research grants and venture capital funding. Journal of Business Venturing 33 (1), 35-51.

Jaffe, A.B., 1989. Real effects of academic research. The American Economic Review 79 (5), 957970.

Jaffe, A.B., de Rassenfosse, G., 2017. Patent citation data in social science research: Overview and best practices. Journal of the Association for Information Science and Technology 68 (6), $1360-1374$.

Jaffe, A.B., Trajtenberg, M., 1996. Flows of knowledge from universities and federal laboratories: Modeling the flow of patent citations over time and across institutional and geographic boundaries. Proceedings of the National Academy of Sciences 93 (23), 1267112677.

Katila, R., Rosenberger, J.D., Eisenhardt, K.M., 2008. Swimming with sharks: Technology ventures, defense mechanisms and corporate relationships. Administrative Science Quarterly 53 (2), 295-332.

Kerr, W.R., Lerner, J., Schoar, A., 2014. The consequences of entrepreneurial finance: Evidence from angel financings. The Review of Financial Studies 27 (1), 20-55.

Knight, B., 2002. Endogenous federal grants and crowd-out of state government spending: Theory and evidence from the federal highway aid program. The American Economic Review 92 (1), 71-92.

Koonin, S.E., Gopstein, A.M., 2011. Accelerating the pace of energy change. Issues in Science and Technology XXVII (2), Winter 2011. Accessed November 12, 2017: http://issues.org/20272012/koonin/.

Laursen, K., Salter, A., 2006. Open for innovation: The role of openness in explaining innovation performance among U.K. Manufacturing firms. Strategic Management Journal 27 (2), 131 150.

Laursen, K., Salter, A.J., 2014. The paradox of openness: Appropriability, external search and collaboration. Research Policy 43 (5), 867-878.

Lavie, D., 2006. The competitive advantage of interconnected firms: An extension of the resourcebased view. Academy of Management Review 31 (3), 638-658.

Lavie, D., 2007. Alliance portfolios and firm performance: A study of value creation and appropriation in the U.S. software industry. Strategic Management Journal 28 (12), 11871212.

Lavie, D., Drori, I., 2012. Collaborating for knowledge creation and application: The case of nanotechnology research programs. Organization Science 23 (3), 704-724.

Lawler, E.J., Yoon, J., 1996. Commitment in exchange relations: Test of a theory of relational cohesion. American Sociological Review 61 (1), 89-108.

Lechner, C., Dowling, M., Welpe, I., 2006. Firm networks and firm development: The role of the relational mix. Journal of Business Venturing 21 (4), 514-540.

Levin, R., Klevorick, A., Nelson, R., Winter, S., 1987. Appropriating the returns from industrial research and development. Brookings Papers on Economic Activity 3, 783-820.

Leyden, M., Link, A., 2015. Public sector entrepreneurship: US technology and innovation policy. Oxford University Press: New York.

Li, M., 2012. Using the propensity score method to estimate causal effects: A review and practical guide. Organizational Research Methods 16 (2), 188-226. 
Liebeskind, J.P., Oliver, A.L., Zucker, L., Brewer, M., 1996. Social networks, learning, and flexibility: Sourcing scientific knowledge in new biotechnology firms. Organization Science 7 (4), 428-443.

Ling, K., 2015. Bipartisan legacy endangered as competes hits house floor, Accessed September 10, 2018: http://www.eenews.net/stories/1060018703.

Logar, N., Anadon, L.D., Narayanamurti, V., 2014. Reforming U.S. energy innovation institutions: Maximizing the return on investment, in: Anadon, L.D., Bunn, M., Narayanamurti, V. (Eds.), Transforming US energy innovation. Cambridge University Press: Cambridge, UK, pp. 81121.

Malecki, E.J., Poehling, R.M., 1999. Extroverts and introverts: Small manufacturers and their information sources. Entrepreneurship \& Regional Development 11 (3), 247-268.

Martin, B.R., 2016. R\&D policy instruments - a critical review of what we do and don't know. Industry and Innovation 23 (2), 157-176.

Mazzucato, M., 2013. The entrepreneurial state - debunking public vs. private sector myths. Anthem Press: London, UK.

Mowery, D., Rosenberg, N., 1979. The influence of market demand upon innovation: A critical review of some recent empirical studies. Research Policy 8 (2), 102-153.

Mowery, D.C., Nelson, R.R., Martin, B.R., 2010. Technology policy and global warming: Why new policy models are needed (or why putting new wine in old bottles won't work). Research Policy 39 (8), 1011-1023.

Musiolik, J., Markard, J., Hekkert, M., 2012. Networks and network resources in technological innovation systems: Towards a conceptual framework for system building. Technological Forecasting and Social Change 79 (6), 1032-1048.

Musiolik, J., Markard, J., Hekkert, M., Furrer, B., 2018. Creating innovation systems: How resource constellations affect the strategies of system builders. Technological Forecasting and Social Change. Forthcoming.

Nanda, R., Younge, K., Fleming, L., 2015. Innovation and entrepreneurship in renewable energy, in: Jaffe, A., Jones, B. (Eds.), The changing frontier: Rethinking science and innovation policy. University of Chicago Press: Chicago, pp. 199-232.

Narayanamurti, V., Odumosu, T., 2016. Cycles of invention and discovery. Harvard University Press: Cambridge, MA.

Nemet, G.F., 2009. Demand-pull, technology-push, and government-led incentives for nonincremental technical change. Research Policy 38 (5), 700-709.

Nemet, G.F., 2018. How solar energy became cheap: A model for low-carbon innovation. Accessed November 20, 2018: https://gregnemet.net/solar-book. ${ }^{10}$

Nemet, G.F., 2012. Inter-technology knowledge spillovers for energy technologies. Energy Economics 34 (5), 1259-1270.

Nemet, G.F., Johnson, E., 2012. Do important inventions benefit from knowledge originating in other technological domains? Research Policy 41 (1), 190-200.

Nordhaus, T., Jenkins, J., Trembath, A., Shellenberger, M., 2012. US government role in shale gas fracking history: An overview, Accessed March 31, 2018:

https://thebreakthrough.org/archive/shale_gas_fracking_history_and.

10 We include the reference to the webpage until the forthcoming book will be published. 
NRC, 2001. Energy research at DOE was it worth it? Energy efficiency and fossil energy research 1978 to 2000, Board on Energy and Environmental Systems, National Research Council (NRC). Accessed September 10, 2018: https://www.nap.edu/catalog/10165/energy-researchat-doe-was-it-worth-it-energy-efficiency.

NSF, 2016. Science and engineering indicators 2016, Accessed November 1, 2018: https://www.nsf.gov/statistics/2016/nsb20161/\#/.

Pfeffer, J., Salancik, G.R., 1978. The external control of organizations: A resource dependence perspective. Harper \& Row: New York.

Pless, J., 2018. Are "complementary policies" substitutes? Evidence from R\&D subsidies in the UK, Accessed October 3, 2018:

https://www.economics.ox.ac.uk/materials/jm_papers/4976/jmp08nov2018pless.pdf.

Popp, D., 2004. Entice: Endogenous technological change in the DICE model of global warming. Journal of Environmental Economics and Management 48 (1), 742-768.

Powell, W.W., Koput, K.W., Smith-Doerr, L., 1996. Interorganizational collaboration and the locus of innovation: Networks of learning in biotechnology. Administrative Science Quarterly 41 (1), 116-145.

Qiu, Y., Anadon, L.D., 2012. The price of wind power in China during its expansion: Technology adoption, learning-by-doing, economies of scale, and manufacturing localization. Energy Economics 34 (3), 772-785.

R Core Team, 2015. R: A language and environment for statistical computing. R Foundation for Statistical Computing, Vienna, Austria.

Rawhouser, H., Villanueva, J., Newbert, S.L., 2016. Strategies and tools for entrepreneurial resource access: A cross-disciplinary review and typology. International Journal of Management Reviews 19 (4), 473-491.

Riordan, M., Hoddeson, L., 1998. Crystal fire: The invention of the transistor and the birth of the information age. Norton: New York et al.

Robinson, D.T., Stuart, T.E., 2007. Network effects in the governance of strategic alliances. Journal of Law, Economics, and Organization 23 (1), 242-273.

Sá, C.M., Litwin, J., 2011. University-industry research collaborations in Canada: The role of federal policy instruments. Science and Public Policy 38 (6), 425-435.

Samila, S., Sorenson, O., 2010. Venture capital as a catalyst to commercialization. Research Policy 39 (10), 1348-1360.

Schacht, W.H., 2009. The Bayh-Dole Act: Selected issues in patent policy and the commercialization of technology, Accessed January 5, 2018: https://fas.org/sgp/crs/misc/RL32076.pdf.

Schilling, M.A., Phelps, C.C., 2007. Interfirm collaboration networks: The impact of large-scale network structure on firm innovation. Management Science 53 (7), 1113-1126.

Schmidt, T.S., Sewerin, S., 2018. Measuring the temporal dynamics of policy mixes - an empirical analysis of renewable energy policy mixes' balance and design features in nine countries. Research Policy, Forthcoming.

Siegel, D.S., Veugelers, R., Wright, M., 2007. Technology transfer offices and commercialization of university intellectual property: Performance and policy implications. Oxford Review of Economic Policy 23 (4), 640-660.

Stock, J., Watson, M., 2007. Introduction to econometrics. Addison-Wesley: Boston. 
Stone, S.I., Rose, R.A., 2011. Social work research and endogeneity bias. Journal of the Society for Social Work and Research 2 (2), 54-75.

Stuart, T.E., 2000. Interorganizational alliances and the performance of firms: A study of growth and innovation rates in a high-technology industry. Strategic Management Journal 21 (8), 791-811.

Trajtenberg, M., 1990. A penny for your quotes: Patent citations and the value of innovations. The RAND Journal of Economics 21 (1), 172-187.

UNFCCC, 2015a. 20 major economies to double clean energy R\&D. United Nations Framework Convention on Climate Change, Accessed February 20, 2018: $\mathrm{http} / / /$ newsroom.unfccc.int/clean-energy/mission-innovation-clean-energy/.

UNFCCC, 2015b. Adoption of the Paris agreement. United Nations Framework Convention on Climate Change, Accessed February 10, 2018:

http://unfccc.int/files/essential_background/convention/application/pdf/english_paris_agreem ent.pdf.

United Nations, 2015. Transforming our world: The 2030 agenda for sustainable development, Accessed February 15, 2018:

http://www.un.org/ga/search/view_doc.asp?symbol=A/RES/70/1\&Lang=E.

Unruh, G.C., 2000. Understanding carbon lock-in. Energy Policy 28 (12), 817-830.

USA.gov, 2018. A-Z index of U.S. government departments and agencies, Accessed November 10, 2018: https://www.usa.gov/federal-agencies/a.

von Hippel, E., 1978. A customer-active paradigm for industrial product idea generation. Research Policy 7 (3), 240-266.

von Hippel, E., 1988. The sources of innovation. Oxford University Press: New York.

Westwick, P.J., 2003. The national labs: Science in an American system, 1947 - 1974. Harvard University Press: Cambridge, MA.

Wright, M., Vohora, A., Lockett, A., 2004. The formation of high-tech university spinouts: The role of joint ventures and venture capital investors. The Journal of Technology Transfer 29 (3), 287-310.

Xia, J., Wang, Y., Lin, Y., Yang, H., Li, S., 2016. Alliance formation in the midst of market and network: Insights from resource dependence and network perspectives. Journal of Management 44 (5), 1899-1925.

Zobel, A.-K., Balsmeier, B., Chesbrough, H., 2016. Does patenting help or hinder open innovation? Evidence from new entrants in the solar industry. Industrial and Corporate Change 25 (2), 307-331. 


$\begin{array}{cccc}\text { Partner } & \text { Alliances with } & \text { Three primary } & \text { Startup } \\ \text { characteristics } & \text { the three } & \text { value-creation } \\ \text { mechanisms } & \text { outcome }\end{array}$

Power Resource

Imbalance Complementarity

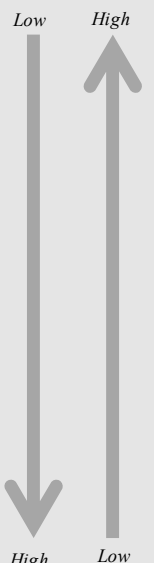

Government

Organizations

Universities \&

Private

Research

Organizations

Private

Sector

Firms

FIGURE 1: Theoretical model on three value-creation mechanisms through alliances for cleantech startups 
Startup - Government

2009

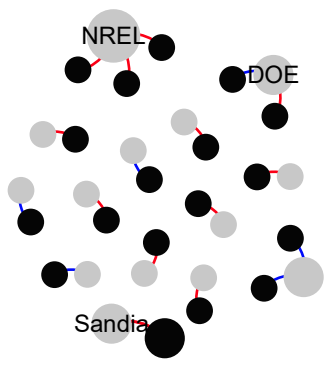

Startup - Government 2011

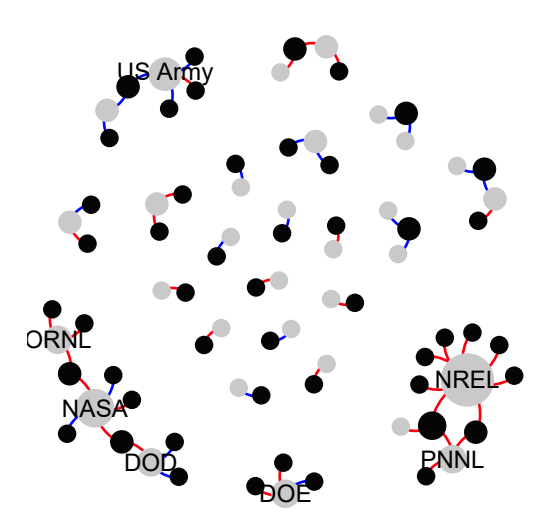

Startup - Government

2010

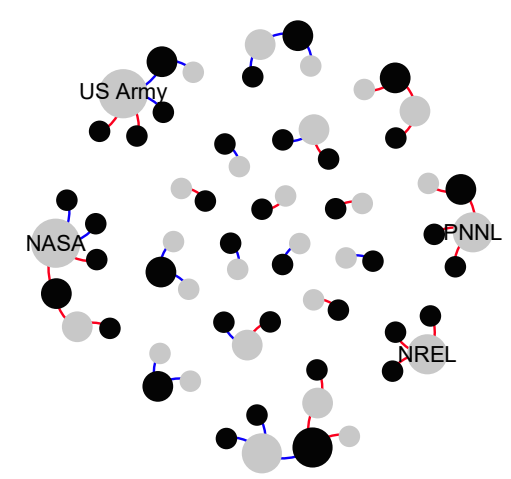

Startup - Government 2012

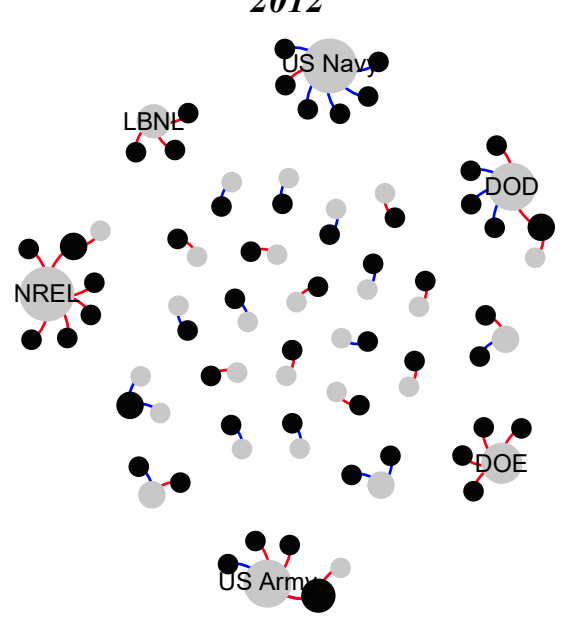

FIGURE 2: Network Graphs

Graph of startup (black) alliances with governmental partners (grey) weighted by the degree centrality from 2009 (top left) to 2012 (bottom-right). The alliances are technology-based (technology development or licensing) (red) or market-based (blue). The most central governmental partners with the highest degree centralities are labeled. 


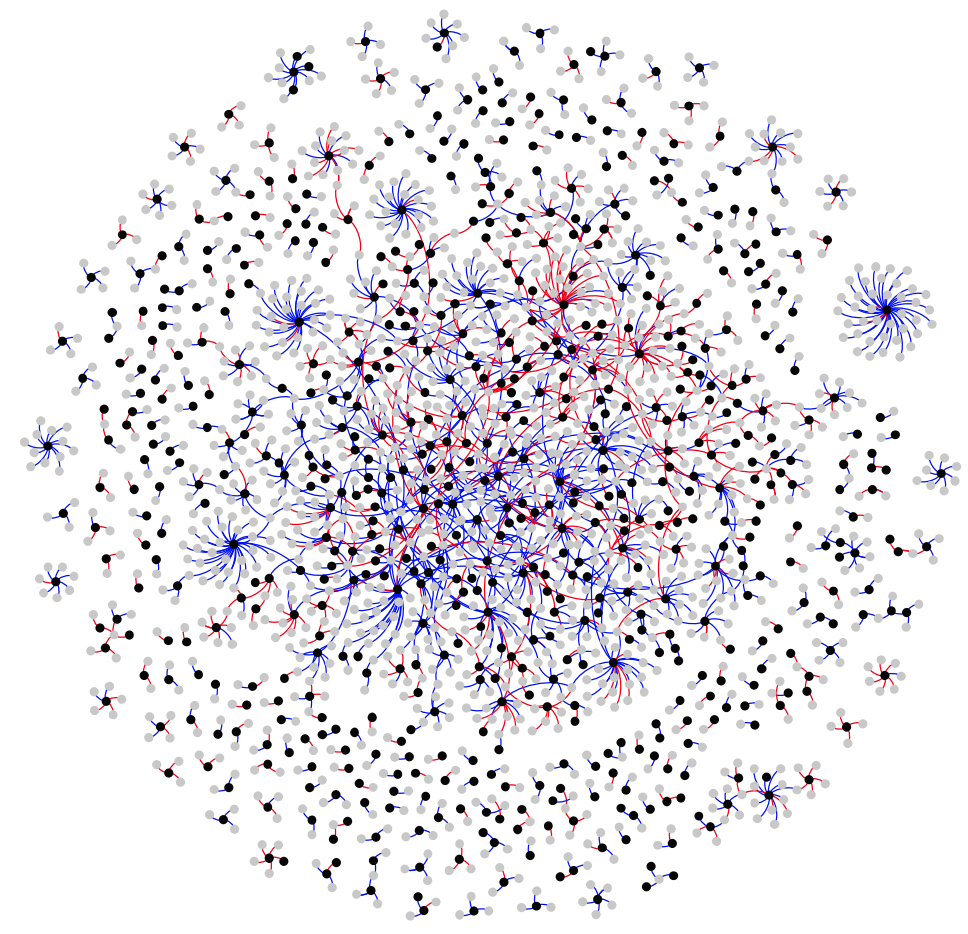

FIGURE 3: Total Network

Graph of startup (black) alliances with other firms (grey) weighted by the degree centrality. The alliances are technology-based (red) or market-based (blue). 


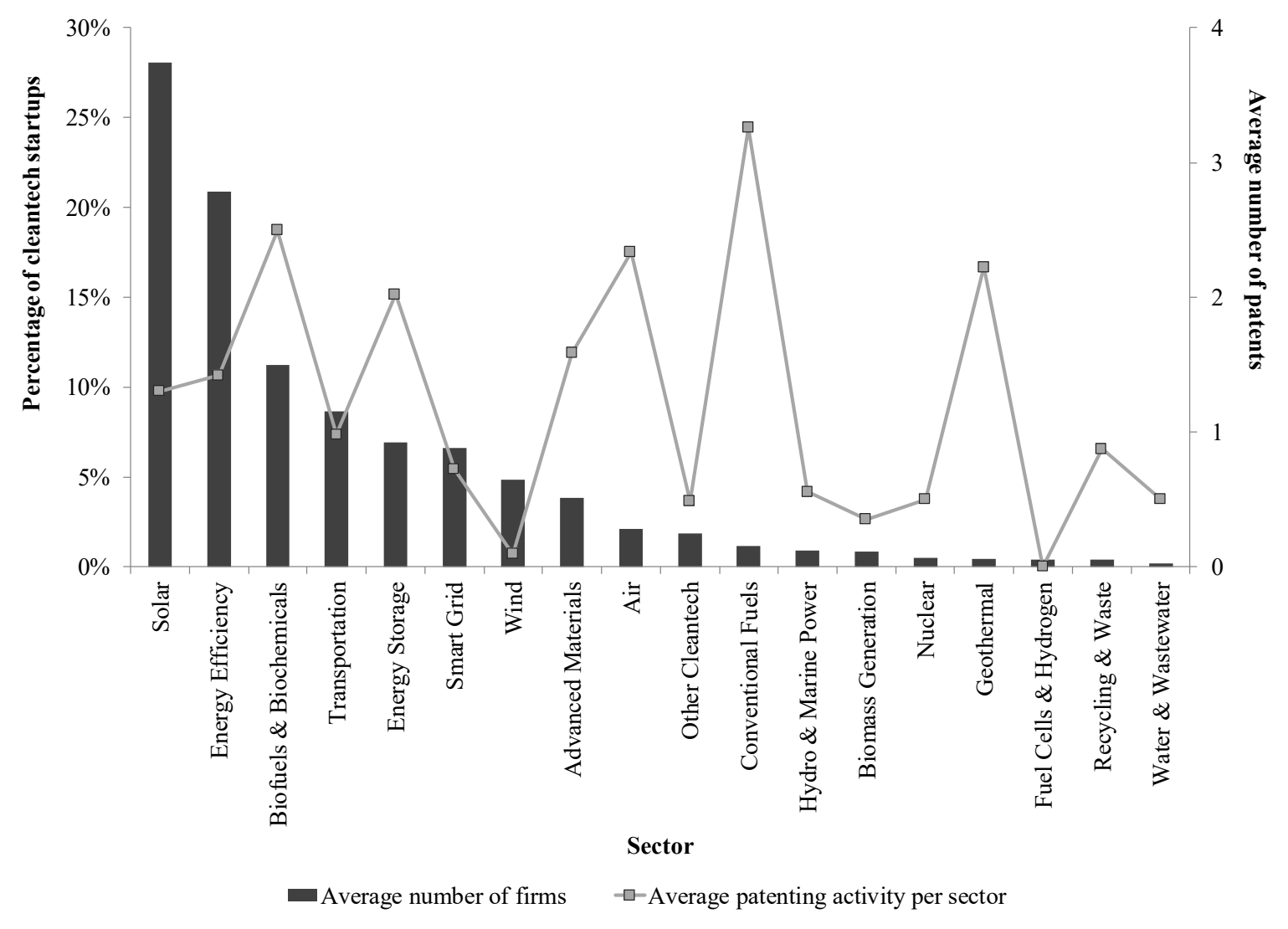

FIGURE 4: Average patenting activity per firm per sector 


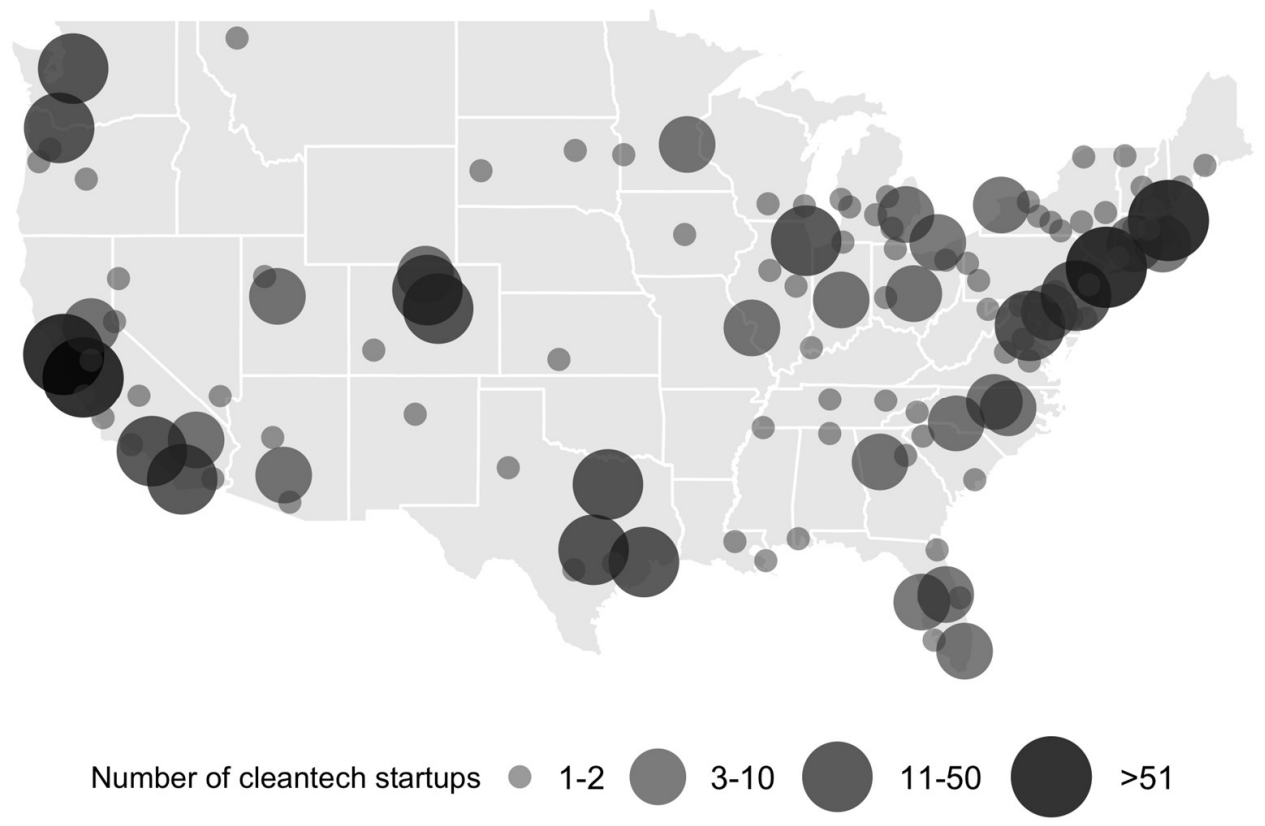

FIGURE 5: Locational distribution of U.S. cleantech startups 
TABLE 1: Overview of network resources from governmental organizations, universities, and firms available to startups to advance innovation in the cleantech sector

\begin{tabular}{|c|c|c|c|}
\hline & Physical resources & Technological resources & Social resources \\
\hline $\begin{array}{l}\text { Governmental } \\
\text { organizations }\end{array}$ & $\begin{array}{l}\text { - Unique scientific user } \\
\text { facilities available to } \\
\text { public and private sector } \\
\text { - Laboratories } \\
\text { - Specialized research } \\
\text { - equipment } \\
\text { - Testing facilities } \\
\text { - Demonstration facilities } \\
\text { - Funding determined } \\
\text { through a political } \\
\text { appropriation process }{ }^{11} \\
\text { (e.g., Bin-Nun et al., 2017; } \\
\text { DOE, 2017; Koonin and } \\
\text { Gopstein, 2011) }\end{array}$ & $\begin{array}{l}\text { - Experience: Dedicated } \\
\text { energy research over several } \\
\text { decades } \\
\text { - Co-located knowledge in } \\
\text { many areas of science and } \\
\text { technology that can be } \\
\text { mobilized } \\
\text { - Knowledge creation abilities } \\
\text { - Large groups of researchers } \\
\text { (multiple laboratories) } \\
\text { - Researchers with long-term } \\
\text { experience } \\
\text { - Relatively low staff impact } \\
\text { turnover } \\
\text { (e.g., Anadon, 2012; Bonvillian, } \\
\text { 2014; Westwick, 2003) }\end{array}$ & $\begin{array}{l}\text { - Mandate to promote } \\
\text { (energy) innovation and } \\
\text { contribute to societal } \\
\text { benefit over a long } \\
\text { timeframe (could be } \\
\text { decades) } \\
\text { - Mandate to help transfer } \\
\text { technology to the } \\
\text { private sector including } \\
\text { commercialization } \\
\text { - Longer funding periods } \\
\text { enable long-term } \\
\text { programs, roadmaps and } \\
\text { goals } \\
\text { (e.g., Anadon et al., 2016; } \\
\text { Bin-Nun et al., 2017; } \\
\text { Cohen and Noll, 1996; } \\
\text { DOE, 2017) }\end{array}$ \\
\hline $\begin{array}{l}\text { Universities and } \\
\text { private research } \\
\text { institutes }\end{array}$ & $\begin{array}{l}\text { - Laboratories } \\
\text { - Specialized research } \\
\text { equipment } \\
\text { - Funding from grants from } \\
\text { public funds, gifts, industry } \\
\text { funded projects, and fees } \\
\text { (e.g., American Academy of } \\
\text { Arts and Sciences, 2013; } \\
\text { Boccanfuso, 2010) }\end{array}$ & $\begin{array}{l}\text { - Experience in longer term } \\
\text { energy related research over } \\
\text { several years } \\
\text { - Diversity of knowledge in } \\
\text { many areas of science and } \\
\text { technology } \\
\text { - Knowledge creation abilities } \\
\text { - Group of researchers at the } \\
\text { scale of a laboratory } \\
\text { - Higher staff fluctuation } \\
\text { (aside from lead } \\
\text { investigators) } \\
\text { (e.g., American Academy of Arts } \\
\text { and Sciences, 2013; Henderson } \\
\text { et al., 1998; Jaffe, 1989) }\end{array}$ & $\begin{array}{l}\text { - Mandate to advance } \\
\text { knowledge and to } \\
\text { educate next generation } \\
\text { - Publications are most } \\
\text { relevant factors for } \\
\text { scientific careers } \\
\text { (knowledge } \\
\text { commercialization often } \\
\text { not a major promotion } \\
\text { criterion) } \\
\text { - Access to future staff } \\
\text { (students) } \\
\text { (e.g., American Academy } \\
\text { of Arts and Sciences, 2013; } \\
\text { Boccanfuso, 2010) }\end{array}$ \\
\hline $\begin{array}{l}\text { Private sector } \\
\text { firms }\end{array}$ & $\begin{array}{l}\text { - Production facilities } \\
\text { - Complementary products } \\
\text { and services } \\
\text { - Funding determined by } \\
\text { market and financial } \\
\text { factors } \\
\text { (e.g., Drucker, 1958) }\end{array}$ & $\begin{array}{l}\text { - Knowledge application } \\
\text { abilities } \\
\text { - Knowledge on market } \\
\text { developments for market- } \\
\text { pull } \\
\text { - Higher staff fluctuation } \\
\text { (e.g., Drucker, 1958) }\end{array}$ & $\begin{array}{l}\text { - Profit orientation } \\
\text { - Lower level of } \\
\text { bureaucracy for } \\
\text { collaboration and } \\
\text { reporting compared to } \\
\text { other partners } \\
\text { (e.g., Drucker, 1958; } \\
\text { Laursen and Salter, 2006) }\end{array}$ \\
\hline
\end{tabular}

11 We included funding in terms of cash available, which can be a physical (tangible) resource. 
TABLE 2: Overview and explanation of the alliance types in the startup database

\begin{tabular}{|c|c|c|}
\hline \multicolumn{2}{|c|}{ Alliance Type } & Example \\
\hline \multirow[t]{2}{*}{$\begin{array}{l}\text { Technology-based } \\
\text { alliances }\end{array}$} & $\begin{array}{l}\text { Technology } \\
\text { development }\end{array}$ & $\begin{array}{l}\text { Arcos Silicon and Broadcom Corporation partnered to } \\
\text { improve the interoperability of their power-over-ethernet } \\
\text { (PoE) products. } \\
\text { Sapphire Power has partnered with University of California, } \\
\text { San Diego to demonstrate the viability of saltwater algae in } \\
\text { the production of biofuels. }\end{array}$ \\
\hline & Licensee & $\begin{array}{l}\text { Natcore has been granted a patent license agreement from } \\
\text { the NREL to develop and commercialize a line of black } \\
\text { silicon PV products. }\end{array}$ \\
\hline \multirow[t]{3}{*}{$\begin{array}{l}\text { Additional forms } \\
\text { of alliances } \\
\text { (included as } \\
\text { controls) }\end{array}$} & $\begin{array}{l}\text { Procurement or } \\
\text { customer }\end{array}$ & $\begin{array}{l}\text { As part of a purchase agreement, Sustainable Green will } \\
\text { become exclusive distributor of MagneGas fuel over a two- } \\
\text { year period in Pacific Northwest. } \\
\text { Avista Corp. is buying the power produced by the Palouse } \\
\text { Wind project under a 30-year power purchase agreement and } \\
\text { will take delivery of the power through a direct interconnect } \\
\text { to the Avista } 230 \mathrm{kV} \text { Benewah-to-Shawnee transmission line. }\end{array}$ \\
\hline & Licensor & $\begin{array}{l}A B B \text { has signed a licensing agreement with ECOtality to use } \\
\text { ECOtality's technology for ABB's EV charging network. }\end{array}$ \\
\hline & $\begin{array}{l}\text { Project } \\
\text { development }\end{array}$ & $\begin{array}{l}\text { Obsidian Renewables partnered with Swinerton Builders to } \\
\text { develop the Black Cap Solar facility. }\end{array}$ \\
\hline
\end{tabular}


TABLE 3: Descriptive statistics of variables used in regression analysis

\begin{tabular}{lcr}
\hline & Mean & S.D. \\
\hline 1 Patenting activity & 1.40 & 3.83 \\
2 Private financing deals & 0.64 & 1.12 \\
3 Government technology alliance & 0.03 & 0.19 \\
4 Government licensing alliance & 0.00 & 0.06 \\
5 Government market alliance & 0.02 & 0.17 \\
6 University/research technology alliance & 0.05 & 0.25 \\
7 University/research licensing alliance & 0.00 & 0.06 \\
8 University/research market alliance & 0.01 & 0.09 \\
9 Inter-firm technology alliance & 0.33 & 0.75 \\
10 Inter-firm licensing alliance & 0.02 & 0.13 \\
11Inter-firm market alliance & 0.52 & 1.34 \\
12 Prior patents & 2.09 & 6.13 \\
13 Prior private financing deals & 1.14 & 1.78 \\
14 Age & 2.46 & 1.60 \\
15 Size (log) & 2.92 & 1.54 \\
16 Location (log MSA density) & 3.11 & 1.45 \\
\hline
\end{tabular}


TABLE 4: Correlations of variables used in regression analysis ( $\mathrm{P}$-values in parentheses)

\begin{tabular}{|c|c|c|c|c|c|c|c|c|c|c|c|c|c|c|c|}
\hline & 1 & 2 & 3 & 4 & 5 & 6 & 7 & 8 & 9 & 10 & 11 & 12 & 13 & 14 & 15 \\
\hline 1 Patenting activity & 1 & & & & & & & & & & & & & & \\
\hline \multirow[t]{2}{*}{2 Private financing deals } & 0.191 & 1 & & & & & & & & & & & & & \\
\hline & $(0.000)$ & & & & & & & & & & & & & & \\
\hline \multirow[t]{2}{*}{3 Government technology alliance } & 0.077 & 0.065 & 1 & & & & & & & & & & & & \\
\hline & $(0.001)$ & $(0.004)$ & & & & & & & & & & & & & \\
\hline \multirow[t]{2}{*}{4 Government licensing alliance } & 0.045 & 0.056 & 0.113 & 1 & & & & & & & & & & & \\
\hline & $(0.044)$ & $(0.013)$ & $(0.000)$ & & & & & & & & & & & & \\
\hline \multirow[t]{2}{*}{5 Government market alliance } & 0.006 & 0.003 & -0.023 & -0.008 & 1 & & & & & & & & & & \\
\hline & $(0.791)$ & $(0.879)$ & $(0.310)$ & $(0.714)$ & & & & & & & & & & & \\
\hline \multirow[t]{2}{*}{6 University/research technology alliance } & 0.026 & 0.039 & 0.124 & 0.02 & -0.012 & 1 & & & & & & & & & \\
\hline & $(0.256)$ & $(0.085)$ & $(0.000)$ & $(0.379)$ & $(0.596)$ & & & & & & & & & & \\
\hline \multirow[t]{2}{*}{7 University/research licensing alliance } & 0.072 & 0.042 & 0.078 & -0.004 & -0.008 & -0.011 & 1 & & & & & & & & \\
\hline & $(0.001)$ & $(0.064)$ & $(0.000)$ & $(0.866)$ & $(0.732)$ & $(0.625)$ & & & & & & & & & \\
\hline \multirow[t]{2}{*}{8 University/research market alliance } & -0.007 & -0.004 & 0.017 & -0.004 & -0.009 & -0.012 & -0.004 & 1 & & & & & & & \\
\hline & $(0.751)$ & $(0.870)$ & $(0.439)$ & $(0.848)$ & $(0.698)$ & $(0.579)$ & $(0.858)$ & & & & & & & & \\
\hline \multirow[t]{2}{*}{9 Inter-firm technology alliance } & 0.148 & 0.184 & 0.056 & 0.067 & 0.063 & 0.106 & -0.015 & 0.038 & 1 & & & & & & \\
\hline & $(0.000)$ & $(0.000)$ & $(0.013)$ & $(0.003)$ & $(0.005)$ & $(0.000)$ & $(0.514)$ & $(0.093)$ & & & & & & & \\
\hline \multirow[t]{2}{*}{10 Inter-firm licensing alliance } & 0.083 & 0.061 & -0.022 & 0.052 & 0.029 & 0.022 & -0.008 & -0.009 & 0.153 & 1 & & & & & \\
\hline & $(0.000)$ & $(0.007)$ & $(0.320)$ & $(0.020)$ & $(0.195)$ & $(0.323)$ & $(0.738)$ & $(0.704)$ & $(0.000)$ & & & & & & \\
\hline \multirow[t]{2}{*}{11 Inter-firm market alliance } & 0.095 & 0.096 & 0.034 & -0.007 & 0.118 & -0.039 & 0.028 & 0.092 & 0.162 & 0.014 & 1 & & & & \\
\hline & $(0.000)$ & $(0.000)$ & $(0.137)$ & $(0.755)$ & 0.000 & $(0.082)$ & $(0.219)$ & $(0.000)$ & $(0.000)$ & $(0.545)$ & & & & & \\
\hline \multirow[t]{2}{*}{12 Prior patents } & 0.639 & 0.173 & 0.035 & 0.006 & 0.04 & -0.009 & 0.032 & 0.036 & 0.15 & 0.058 & 0.13 & 1 & & & \\
\hline & $(0.000)$ & $(0.000)$ & $(0.118)$ & $(0.797)$ & $(0.073)$ & $(0.689)$ & $(0.161)$ & $(0.109)$ & $(0.000)$ & $(0.010)$ & $(0.000)$ & & & & \\
\hline \multirow[t]{2}{*}{13 Prior private financing deals } & 0.268 & 0.456 & 0.091 & 0.037 & 0.038 & 0.011 & 0.066 & 0.001 & 0.248 & 0.104 & 0.176 & 0.357 & 1 & & \\
\hline & $(0.000)$ & $(0.000)$ & $(0.000)$ & $(0.096)$ & $(0.092)$ & $(0.631)$ & $(0.003)$ & $(0.981)$ & $(0.000)$ & $(0.000)$ & $(0.000)$ & $(0.000)$ & & & \\
\hline \multirow[t]{2}{*}{14 Age } & 0.138 & 0.105 & 0.077 & 0.047 & 0.056 & -0.025 & 0.026 & 0.025 & 0.219 & 0.072 & 0.173 & 0.259 & 0.397 & 1 & \\
\hline & $(0.000)$ & $(0.000)$ & $(0.001)$ & $(0.037)$ & $(0.012)$ & $(0.273)$ & $(0.244)$ & $(0.275)$ & $(0.000)$ & $(0.001)$ & $(0.000)$ & $(0.000)$ & $(0.000)$ & & \\
\hline \multirow[t]{2}{*}{15 Size $(\log )$} & 0.261 & 0.242 & 0.031 & 0.028 & -0.001 & -0.05 & -0.011 & 0.016 & 0.114 & -0.029 & 0.192 & 0.26 & 0.348 & 0.21 & 1 \\
\hline & $(0.000)$ & $(0.000)$ & $(0.188)$ & $(0.228)$ & $(0.982)$ & $(0.033)$ & $(0.637)$ & $(0.495)$ & $(0.000)$ & $(0.222)$ & 0.000 & $(0.000)$ & $(0.000)$ & $(0.000)$ & \\
\hline \multirow[t]{2}{*}{16 Location (log MSA density) } & 0.113 & 0.145 & -0.036 & -0.02 & 0.016 & -0.003 & 0.047 & 0.028 & 0.037 & 0.000 & 0.082 & 0.089 & 0.151 & 0.013 & 0.089 \\
\hline & $(0.000)$ & $(0.000)$ & $(0.109)$ & $(0.375)$ & $(0.489)$ & $(0.903)$ & $(0.037)$ & $(0.208)$ & $(0.099)$ & $(0.990)$ & $(0.000)$ & $(0.000)$ & $(0.000)$ & $(0.514)$ & $(0.000)$ \\
\hline
\end{tabular}


TABLE 5: Estimated coefficients from negative binomial regressions

(P-values in parentheses; robust standard errors in brackets)

\begin{tabular}{|c|c|c|c|c|c|c|}
\hline & \multicolumn{3}{|c|}{ Patenting Activity } & \multicolumn{3}{|c|}{ Private Financing Deals } \\
\hline & $\begin{array}{c}(1) \\
\text { Controls } \\
\end{array}$ & $\begin{array}{c}\text { (2) } \\
\text { Partner Type }\end{array}$ & $\begin{array}{c}\text { (3) } \\
\text { Partner and Alliance } \\
\end{array}$ & $\begin{array}{c}(1) \\
\text { Controls } \\
\end{array}$ & $\begin{array}{c}(2) \\
\text { Partner Type } \\
\end{array}$ & $\begin{array}{c}\text { (3) } \\
\text { Partner and Alliance } \\
\end{array}$ \\
\hline Controls & & & & & & \\
\hline Pre-sample ${ }^{1}$ patents / prior patents & $\begin{array}{c}0.070 \\
(0.002) \\
{[0.022]}\end{array}$ & $\begin{array}{c}0.076 \\
(0.001) \\
{[0.023]}\end{array}$ & $\begin{array}{c}0.078 \\
(0.000) \\
{[0.021]}\end{array}$ & $\begin{array}{c}0.005 \\
(0.389) \\
{[0.006]}\end{array}$ & $\begin{array}{c}0.003 \\
(0.631) \\
{[0.006]}\end{array}$ & $\begin{array}{c}0.002 \\
(0.690) \\
{[0.006]}\end{array}$ \\
\hline Prior private financing deals / pre-sample $^{1}$ financing & $\begin{array}{c}0.191 \\
(0.000) \\
{[0.031]}\end{array}$ & $\begin{array}{c}0.172 \\
(0.000) \\
{[0.031]}\end{array}$ & $\begin{array}{c}0.152 \\
(0.000) \\
{[0.030]}\end{array}$ & $\begin{array}{c}0.292 \\
(0.000) \\
{[0.031]}\end{array}$ & $\begin{array}{c}0.293 \\
(0.000) \\
{[0.031]}\end{array}$ & $\begin{array}{c}0.292 \\
(0.000) \\
{[0.030]}\end{array}$ \\
\hline Prior public financing deals & $\begin{array}{c}0.225 \\
(0.118) \\
{[0.144]}\end{array}$ & $\begin{array}{c}0.332 \\
(0.035) \\
{[0.158]}\end{array}$ & $\begin{array}{c}0.367 \\
(0.028) \\
{[0.167]}\end{array}$ & $\begin{array}{c}0.019 \\
(0.893) \\
{[0.138]}\end{array}$ & $\begin{array}{c}0.069 \\
(0.612) \\
{[0.137]}\end{array}$ & $\begin{array}{c}0.071 \\
(0.602) \\
{[0.137]}\end{array}$ \\
\hline Age & $\begin{array}{c}0.067 \\
(0.130) \\
{[0.044]}\end{array}$ & $\begin{array}{c}0.064 \\
(0.149) \\
{[0.044]}\end{array}$ & $\begin{array}{c}0.050 \\
(0.263) \\
{[0.045]}\end{array}$ & $\begin{array}{l}-0.112 \\
(0.000) \\
{[0.028]}\end{array}$ & $\begin{array}{l}-0.128 \\
(0.000) \\
{[0.029]}\end{array}$ & $\begin{array}{l}-0.134 \\
(0.000) \\
{[0.029]}\end{array}$ \\
\hline Size $(\log )$ & $\begin{array}{c}0.390 \\
(0.000) \\
{[0.047]}\end{array}$ & $\begin{array}{c}0.385 \\
(0.000) \\
{[0.049]}\end{array}$ & $\begin{array}{c}0.396 \\
(0.000) \\
{[0.049]}\end{array}$ & $\begin{array}{c}0.206 \\
(0.000) \\
{[0.029]}\end{array}$ & $\begin{array}{c}0.197 \\
(0.000) \\
{[0.029]}\end{array}$ & $\begin{array}{c}0.198 \\
(0.000) \\
{[0.030]}\end{array}$ \\
\hline Location (log MSA density) & $\begin{array}{c}0.224 \\
(0.000) \\
{[0.037]}\end{array}$ & $\begin{array}{c}0.219 \\
(0.000) \\
{[0.037]}\end{array}$ & $\begin{array}{c}0.223 \\
(0.000) \\
{[0.037]}\end{array}$ & $\begin{array}{c}0.147 \\
(0.000) \\
{[0.026]}\end{array}$ & $\begin{array}{c}0.142 \\
(0.000) \\
{[0.026]}\end{array}$ & $\begin{array}{c}0.145 \\
(0.000) \\
{[0.027]}\end{array}$ \\
\hline Partner Types & & & & & & \\
\hline Government partner & & $\begin{array}{c}0.284 \\
(0.047) \\
{[0.143]}\end{array}$ & & & $\begin{array}{c}0.143 \\
(0.241) \\
{[0.121]}\end{array}$ & \\
\hline University/research partner & & $\begin{array}{c}0.236 \\
(0.089) \\
{[0.139]}\end{array}$ & & & $\begin{array}{c}0.005 \\
(0.965) \\
{[0.106]}\end{array}$ & \\
\hline Cleantech young firm partner & & $\begin{array}{c}0.136 \\
(0.188) \\
{[0.104]}\end{array}$ & & & $\begin{array}{c}0.088 \\
(0.178) \\
{[0.065]}\end{array}$ & \\
\hline Other inter-firm partner & & $\begin{array}{c}0.036 \\
(0.309) \\
{[0.035]}\end{array}$ & & & $\begin{array}{c}0.065 \\
(0.001) \\
{[0.020]}\end{array}$ & \\
\hline Nonprofit partner & & $\begin{array}{l}-1.093 \\
(0.193) \\
{[0.840]}\end{array}$ & $\begin{array}{c}-1.174 \\
(0.113) \\
{[0.740]}\end{array}$ & & $\begin{array}{l}-1.235 \\
(0.022) \\
{[0.539]}\end{array}$ & $\begin{array}{l}-1.149 \\
(0.034) \\
{[0.541]}\end{array}$ \\
\hline Other public partner & & $\begin{array}{c}-0.032 \\
(0.897) \\
{[0.249]}\end{array}$ & $\begin{array}{c}0.065 \\
(0.812) \\
{[0.276]}\end{array}$ & & $\begin{array}{c}-0.401 \\
(0.019) \\
{[0.171]}\end{array}$ & $\begin{array}{c}-0.293 \\
(0.081) \\
{[0.168]}\end{array}$ \\
\hline Partner and Alliance Types & & & & & & \\
\hline Government technology alliance & & & $\begin{array}{c}0.552 \\
(0.010) \\
{[0.213]}\end{array}$ & & & $\begin{array}{c}0.248 \\
(0.135) \\
{[0.166]}\end{array}$ \\
\hline Government licensing alliance & & & $\begin{array}{c}0.651 \\
(0.215)\end{array}$ & & & $\begin{array}{c}0.935 \\
(0.009)\end{array}$ \\
\hline
\end{tabular}


University/research technology alliance

University/research licensing alliance

University/research procurement alliance

Inter-firm technology alliance

Inter-firm licensing alliance

Inter-firm procurement alliance

\begin{tabular}{l|l}
{$[0.525]$} & {$[0.358]$}
\end{tabular}

$\begin{array}{cc}-0.046 & -0.164 \\ (0.888) & (0.433) \\ 0.3280 & 0.209)\end{array}$

$[0.327]-[0.209]$

$\begin{array}{lll}0.288 & -0.031\end{array}$

$(0.070)-(0.806)$

\begin{tabular}{l|c}
{$[0.159]$} & {$[0.125$} \\
1.297 & 0.705 \\
$(0.001)$ & $0.082)$
\end{tabular}

$(0.001)-(0.082)$

$[0.400]-[0.405]$

\begin{tabular}{l|l}
-0.796 & -0.227 \\
\hline 0.100 & $-4077)$
\end{tabular}

$(0.100)$

$[0.484]-[0.319]$

$0.218-0.180$

$(0.000)-(0.000)$

$[0.059] \quad[0.040]$

$\begin{array}{ll}0.511 & 0.082 \\ 0.087) & (0.685)\end{array}$

-

$[0.203]$

\begin{tabular}{c|c}
0.013 & 0.035 \\
$(0.754)$ & $(0.174)$ \\
{$[0.041]$} & {$[0.025]$}
\end{tabular}

Additional Alliances

Project development alliance

Licensor alliance

$(0.367)$

$[0.088]$

0.147
$(0.639)$

lnalpha

[0.314]

Inalpha

Constant

Sector FE

Year FE

1.151

$(0.000)$

$[0.068]$
-2.661

-2.661
$(0.000)$

Year FE

1.213
$(0.000)$
$[0.065]$

$[0.065] \quad(0.000)$

$[0.066]$
-2.696

$\begin{array}{ll}-2.721 & -2.696 \\ (0.000) & (0.000)\end{array}$

[0.247]

\section{Observations}

Pseudo R2 (McFadden) ${ }^{2}$

YES YES

Prob $>$ chi2

YES

Log Lokelihood

2. We repo 